Article

\title{
Trace Element Analysis of Pyrite from the Zhengchong Gold Deposit, Northeast Hunan Province, China: Implications for the Ore-Forming Process
}

\author{
Yong-Jun Shao ${ }^{1}$, Wen-Shu Wang ${ }^{1}$, Qing-Quan Liu ${ }^{1,2, *}$ and Yu Zhang ${ }^{1}$ \\ 1 Key Laboratory of Metallogenic Prediction of Nonferrous Metals and Geological Environment Monitoring, \\ Ministry of Education, School of Geosciences and Info-Physics, Central South University, \\ Changsha 410083, China; shaoyongjun@126.com (Y.-J.S.); wangwswin@163.com (W.-S.W.); \\ zyu2005@csu.edu.cn (Y.Z.) \\ 2 School of Resources and Safety Engineering, Central South University, Changsha 410083, China \\ * Correspondence: liuqingquan@csu.edu.cn
}

Received: 1 June 2018; Accepted: 15 June 2018; Published: 20 June 2018

check for updates

\begin{abstract}
The Zhengchong gold deposit is located in the central segment of the Jiangnan Orogen in northeastern Hunan Province, South China. The host rocks of this deposit are the Neoproterozoic slates of the Lengjiaxi Group and granodiorite. The structures in the Zhengchong gold deposit are dominated by NE-trending reverse faults, which control the gold-bearing veins. The orebody consists of NE-trending laminated quartz veins and NW-trending quartz veins. The alteration styles include silicification, carbonatization, sulfidation, sericitization and chloritization. The Zhengchong gold mineralization can be divided into four stages: Quartz-pyrite (stage I), quartz-pyrite-arsenopyrite (stage II), quartz-polysulfide (stage III) and quartz-carbonate (stage IV). Three generations of hydrothermal pyrite were identified: Disseminated euhedral to subhedral cubes in altered wall-rock (PyI), euhedral to subhedral cubes inter-grown with arsenopyrite and tetrahedrite in quartz veins and wall-rock (PyII), and euhedral cubes with microinclusions (native gold, galena, sphalerite, chalcopyrite, tetrahedrite, and pyrrhotite) or metasomatic textures in sulfide-rich veins or veinlets (PyIII). PyII and PyIII are arsenian pyrite and represent the main Au-bearing minerals. PyI records the lowest concentrations of $\mathrm{Au}$; PyII and PyIII record similar amounts of $\mathrm{Au}, \mathrm{Cu}, \mathrm{Pb}, \mathrm{Zn}$, and $\mathrm{Bi}$, but PyIII is more enriched in $\mathrm{Co}, \mathrm{Ni}, \mathrm{Te}$, and Se. The substitution of As, Se and Te for $\mathrm{S}$ and that of $\mathrm{Co}$ and $\mathrm{Ni}$ for Fe occurs by direct-ion exchange. Invisible gold is uniformly distributed within the arsenian pyrite, and visible gold fills microfractures in PyII or occurs as inclusions in PyIII. Co, Ni, $\mathrm{Cu}$ exhibit positive correlations with $\mathrm{Au}$ and a negative correlation between $\mathrm{Au}+\mathrm{Cu}+\mathrm{Co}+\mathrm{Ni}$ and Fe reflect that Fe vacancies may have been a major cause of the precipitation of invisible Au and other metal elements in pyrite structure. There are systematic trace element differences between the three generations of pyrite (PyI, PyII, PyIII). The more Co, Ni and Se, Te substitution that occurred for $\mathrm{Fe}$ and $\mathrm{S}$, respectively, the greater the increase in the $\mathrm{Co} / \mathrm{Ni}$ ratio $(<1)$ and the decrease in the $\mathrm{Se} / \mathrm{Te}$ ratio $(<10)$ in stage III, indicating that a more reduced, lower-temperature metamorphic hydrothermal fluid was present in stage III.
\end{abstract}

Keywords: pyrite; trace element; gold deposit; Zhengchong; Northeast Hunan Province

\section{Introduction}

Gold deposits in metamorphic terranes can be classified as orogenic gold deposits or reduced intrusion-related gold deposits [1-3]. Orogenic gold deposits dominantly form in greenstone belts, 
at or above the brittle-ductile transition, with weakly reduced, low-salinity fluids with near-neutral $\mathrm{pH}$ values at approximately $300{ }^{\circ} \mathrm{C}[1,4-8]$. In contrast, reduced intrusion-related gold deposits are intrusion-hosted, sheeted arrays of thin, low-sulfide quartz veins with $\mathrm{Au}-\mathrm{Bi}-\mathrm{Te}-\mathrm{W}$ signatures $[2,6]$. Some models have explained the role of fluids in gold mineralization, including a decrease in solubility that occurs during drops in pressure associated with earthquakes in the case of quartz veins $[9,10]$ and the destabilization of gold bisulfide complexes by a redox reaction that occurs between the transporting fluid and iron in the host rocks, which precipitates both pyrite and free gold [7,11].

Current issues in the study of gold deposits include the source of the ore-forming fluids, the precise tectonic setting and age of mineralization, and the specific depositional mechanisms for gold $[3,8]$. The first two controversies are mainly due to the abundance of isotope and fluid inclusion data $[12,13]$ and the lack of ore minerals that have been subjected to high-precision geochronological analysis [14]. However, information about the transport and deposition of gold and its fluid evolution can be obtained using the detailed petrogenetic analyses and trace element data of pyrite [15-18]. Pyrite is stable under a very wide range of sulfur activity and thermodynamic conditions compared to other sulfides $[15,19,20]$. Gold is preferentially concentrated in the crystal structure of arsenian pyrite or as micrometer-size particles [19,21,22]. It is possible to identify the gold mineralization in the Zhengchong deposit based on the presence of arsenian pyrite.

The Jiangnan Orogenic Belt (JOB), which is located in South China (Figure 1a), hosts more than $250 \mathrm{Au}$-(polymetallic) deposits and contains more than $960 \mathrm{t}$ of total gold reserves [23,24]. Northeastern Hunan Province (NEHP) contains approximately $125 \mathrm{Au}$-(polymetallic) deposits, including the Wangu, Huangjindong and Yanlinsi deposits (Figure 1b) [24]. The Zhengchong gold deposit is a new exploration area in the Yanlinsi orefield. However, the ore genesis of the deposits in the Jiangnan Orogen is not well understood [23]. Various genetic models have been proposed for the deposits in the JOB, including orogenic, epithermal, intrusion-related, and even SEDEX-type models [25-33].

Here, we provide textural, EPMA and LA-ICP-MS data for Au and the other trace elements in the pyrite from the Zhengchong deposit. In this contribution, we show that systematic differences exist between different generations of pyrite, and we use these data to better understand the evolution stages of ore systems and characterize their ore-forming processes. 


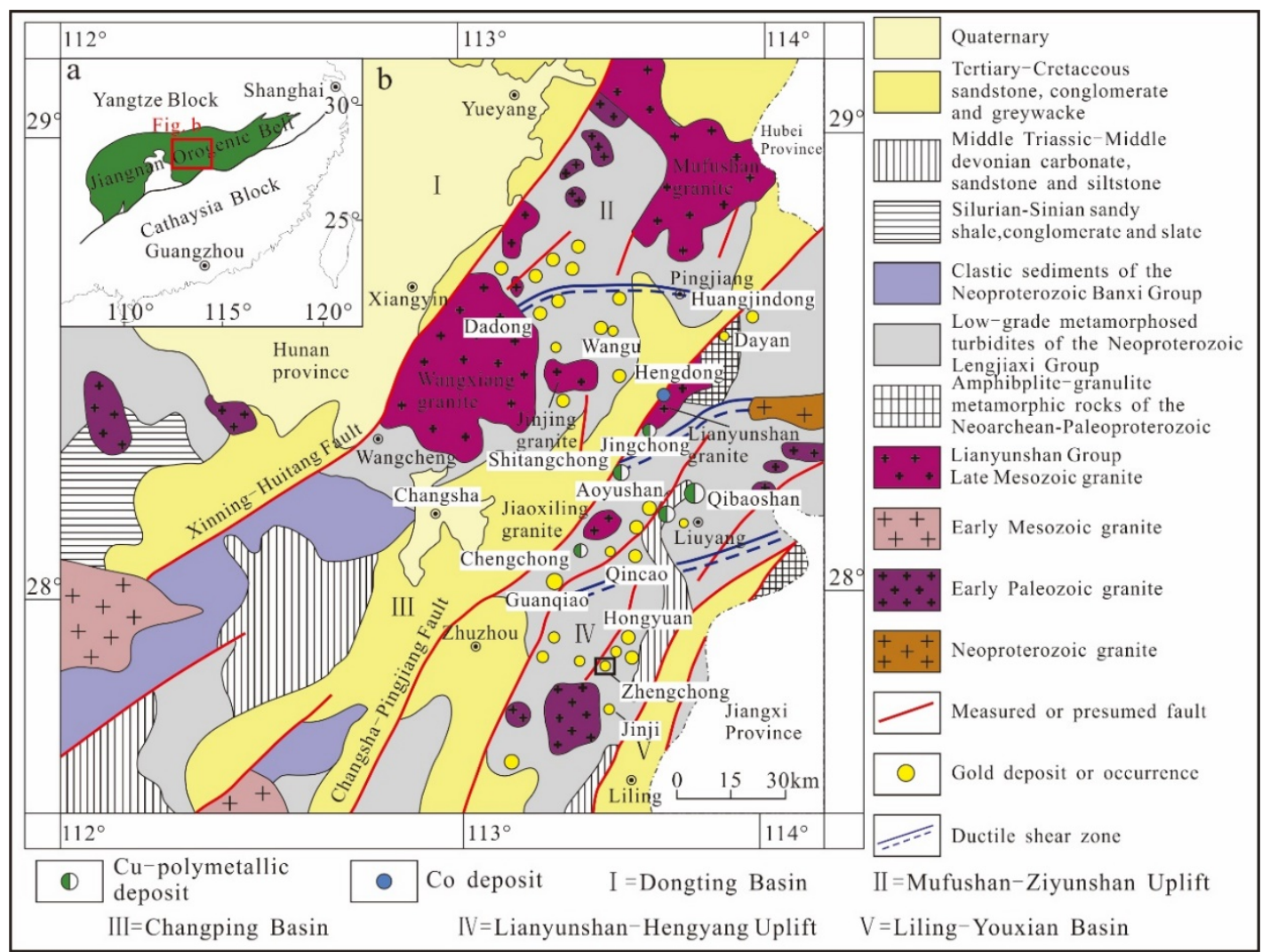

Figure 1. (a) Simplified map of South China; (b) geological sketch map of northeastern Hunan Province showing the tectonic, magmatic and stratigraphic framework as well as the dominant $\mathrm{Au}-, \mathrm{Cu}-$ and Co (-polymetallic) ore deposits (modified after [23]).

\section{Geological Setting}

\subsection{Regional Geology}

The JOB is a Neoproterozoic collisional zone located between the Yangtze Block to the northwest and the Cathaysia Block to the southeast (Figure 1a) [34-38].

The NEHP is located in the central part of the JOB. The lithostratigraphic units in this region consist of Neoproterozoic Lengiaxi Group (LJXG) low-grade metamorphic volcaniclastic and sedimentary rocks and Meso-Cenozoic red-bed sedimentary rocks, with minor Archean to Paleoproterozoic crystalline metamorphic rocks and Paleozoic sedimentary rocks [24]. A Basin-and-Range-style tectonic setting (Figure 1b), comprising extensional basins and granitic domes, as well as marginal strike-slip faults, formed during the late Mesozoic [24,39-41]. Most of the granites in the JOB have been interpreted as S-type granites that formed from the Proterozoic, Early Paleozoic (Caledonian), and Early Mesozoic (Indosinian) to the Late Mesozoic (Yanshanian) [24,39,42].

\subsection{Deposit Geology}

The Zhengchong gold deposit is hosted in the Neoproterozoic lower and upper Huanghudong and lower Xiaomuping formations of the LJXG (Figure 2). These rocks are all NE-striking and dip to the NW at $26^{\circ}-65^{\circ}$, indicating that they comprise a reverse anticline. The lower Huanghudong Formation is a suite of flysch turbidites that is mainly composed of greywacke, slate and silty slates. The upper Huanghudong Formation consists of grayish metamorphic quartz greywacke, siltstones, slate and silty slates. The lower Xiaomuping Formation is composed of pale yellow slate and silty slates. The altered granodiorite that is exposed in the central part of the Zhengchong deposit has 
experienced carbonatization, sulfidation, and sericitization (Figures 2 and 3f). The NW-trending QCVs are always associated with strong alteration.

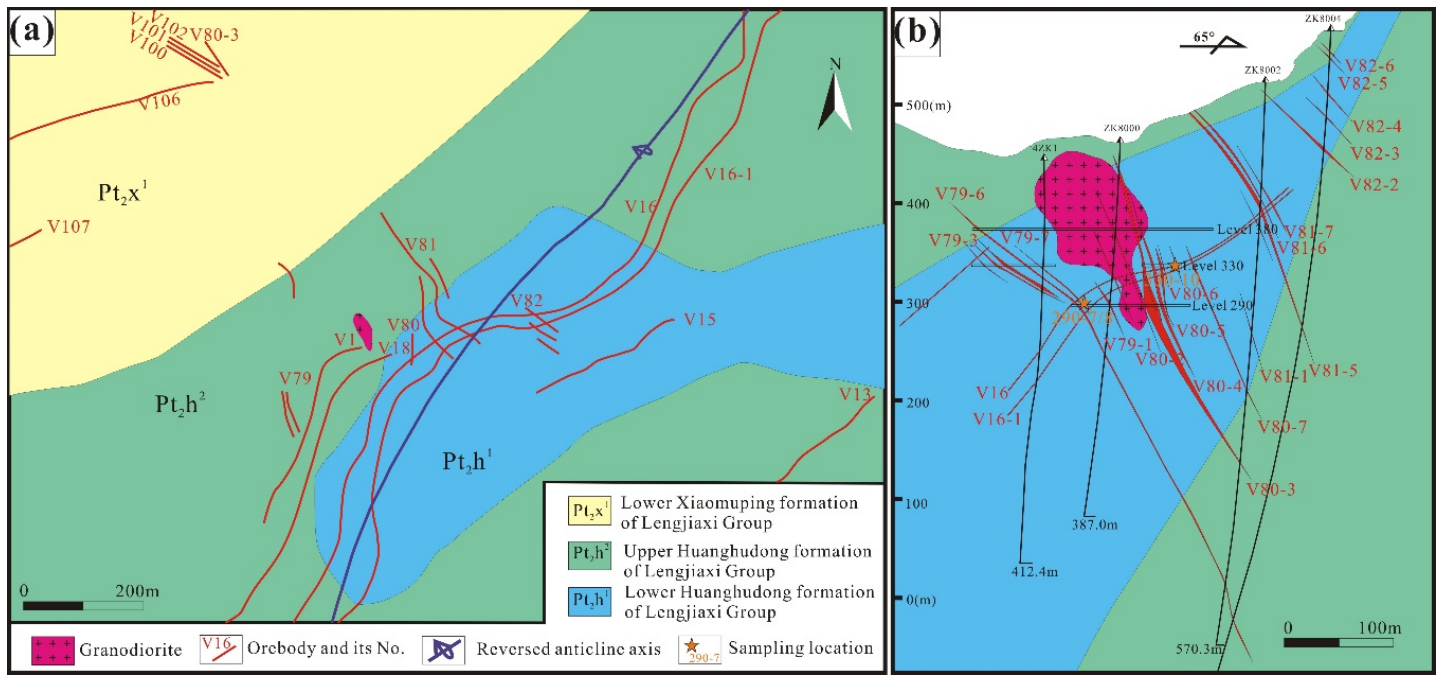

Figure 2. (a) Geological map of the Zhengchong gold deposit; (b) cross-section showing geological features of the ore and the host rocks of the deposit, including sampling location.
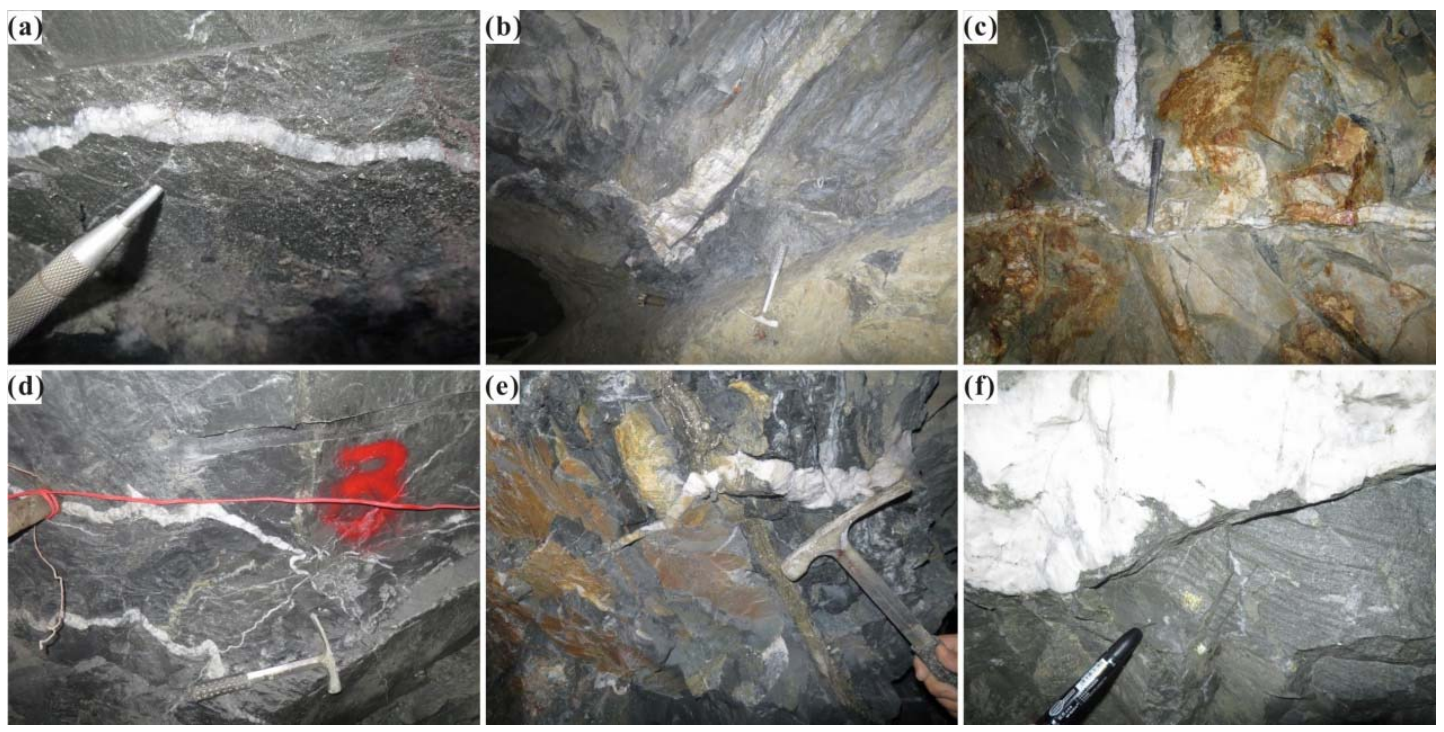

Figure 3. Photographs of various vein types in the Zhengchong Au deposit. (a) Disseminated pyrite and arsenopyrite in vein and country rock; (b) representative NE-trending laminated quartz veins. (c) Laminated quartz vein (NE) cuts through an earlier quartz-pyrite vein (NW) in granodiorite. (d) Stockwork veins and massive pyrite vein are cut by disseminated pyrite vein, and they are all cut by quartz-carbonate vein. (e) Massive pyrite vein and laminated quartz vein cut by barren quartz-carbonate vein. (f) Disseminated pyrite vein and pyrite pebble.

The orebody contains Au-bearing quartz veins that range in thickness from centimeters to meters and consist of quartz, carbonate, pyrite, arsenopyrite, and native gold. There are two sets of quartz veins in the deposit: (1) NE-trending laminated quartz veins (Figure 3b) and (2) NW-trending quartz veins, which are more complicated and include disseminated pyrite and arsenopyrite in and around veins (Figure 3a), massive pyrite veins (Figure 3d,e) and disseminated pyrite veins (Figure 3c-f). These Au-bearing quartz veins are hosted in strata and altered granodiorite. The gold mineralization is closely associated with carbonatization, sulfidation, sericitization and chloritization (Figure 4). 
Based on the mineralogical and textural characteristics of the ore minerals and the crosscutting relationships between the mineralized veins (Figure 3), four mineralization stages were recognized (Figure 5). These stages are the quartz-pyrite (stage I), quartz-pyrite-arsenopyrite (stage II), quartz-polysulfide (stage III) and quartz-carbonate (stage IV) stages. Stages II and III are considered to be the main stages of ore formation.
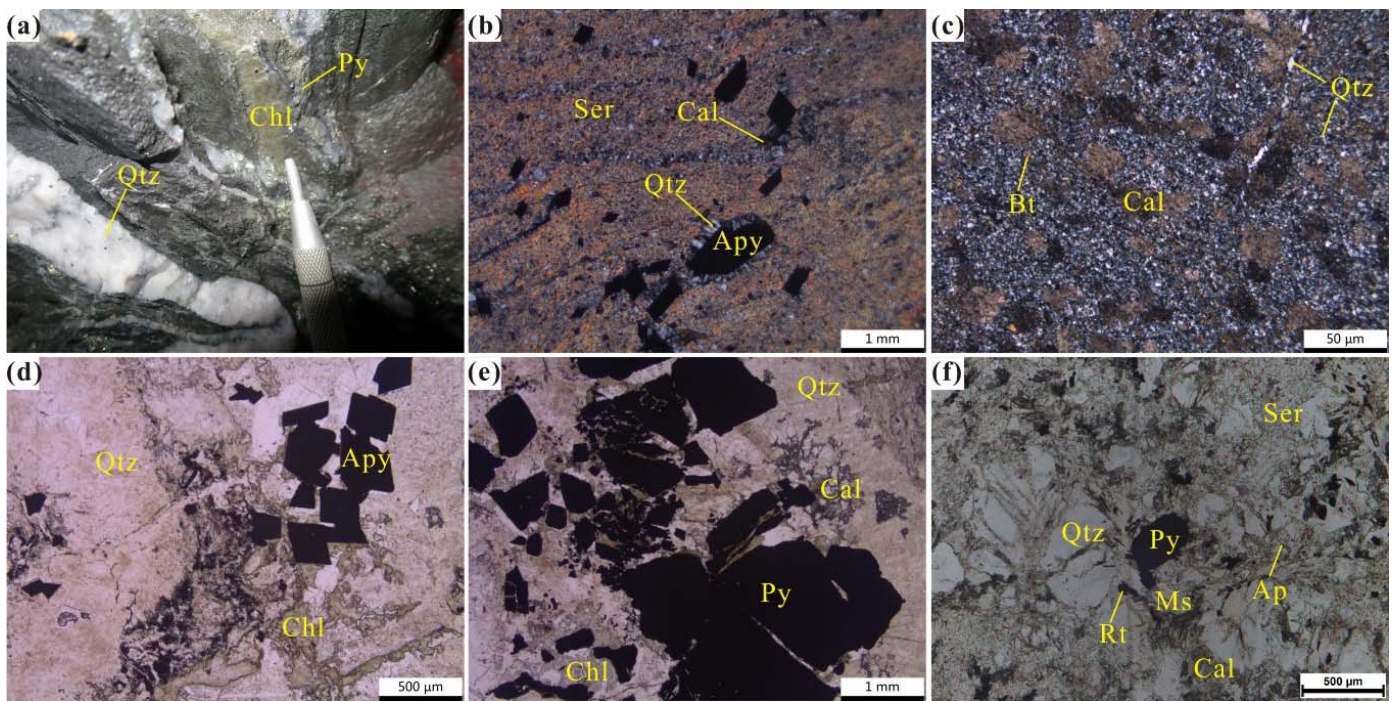

Figure 4. Photographs of various alteration assemblages in the Zhengchong Au deposit. (a) Chlorite vein near quartz veins near massive pyrite vein and disseminated pyrite vein. (b) Crossed nicols photomicrograph of pyrite with quartz strain fringes exhibiting sericitization. (c) Crossed nicols photomicrograph of carbonatization in country rock. (d) Parallel nicols photomicrograph of chlorite inter-grown with arsenopyrite in quartz vein. (e) Parallel nicols photomicrograph of chlorite and carbonate around breccia pyrite in pyrite pebble. (f) Crossed nicols photomicrograph of altered granodiorite, including carbonatization, sulfidation, and sericitization. Qtz-quartz; Cal—carbonate; Ser—sericite; Ms—muscovite; Chl—chlorite; Ap—apatite; Py—pyrite; Rt—rutile.

\begin{tabular}{|c|c|c|c|c|}
\hline \multirow{2}{*}{ Minerals } & Mineralization & \multicolumn{5}{|c|}{ Hydrothermal Period } \\
\hline & Stage I & Stage II & Stage III & Stage IV \\
\hline Pyrite & & & & \\
\hline Arsenopyrite & & & & \\
\hline Tetrahedrite & & & & \\
\hline Visible gold & & & & \\
\hline Galena & & & & \\
\hline Chalcopyrite & & & & \\
\hline Sphalerite & & & & \\
\hline Pyrrhotite & & & - & \\
\hline Quartz & & & & \\
\hline Carbonate & & & & \\
\hline Sericite & & & & \\
\hline Chlorite & & & & \\
\hline Rutile & & & & \\
\hline & & & & \\
\hline
\end{tabular}

Figure 5. Paragenetic sequence of the Zhengchong gold deposit. 


\section{Samples and Analytical Methods}

\subsection{Sample Sites}

To obtain a more complete picture of the evolution of the ore-forming hydrothermal fluids and the genetic model of gold deposition for the Zhengchong Au deposit, three samples were collected from tunnels at different levels (Figure 2b) based on their cross-cutting relationships and differences in mineralization between veins. Detailed descriptions of the analyzed samples are given in Table 1.

Table 1. Location, host rock, general description and ore minerals of the analyzed samples from the Zhengchong deposit (wt \%).

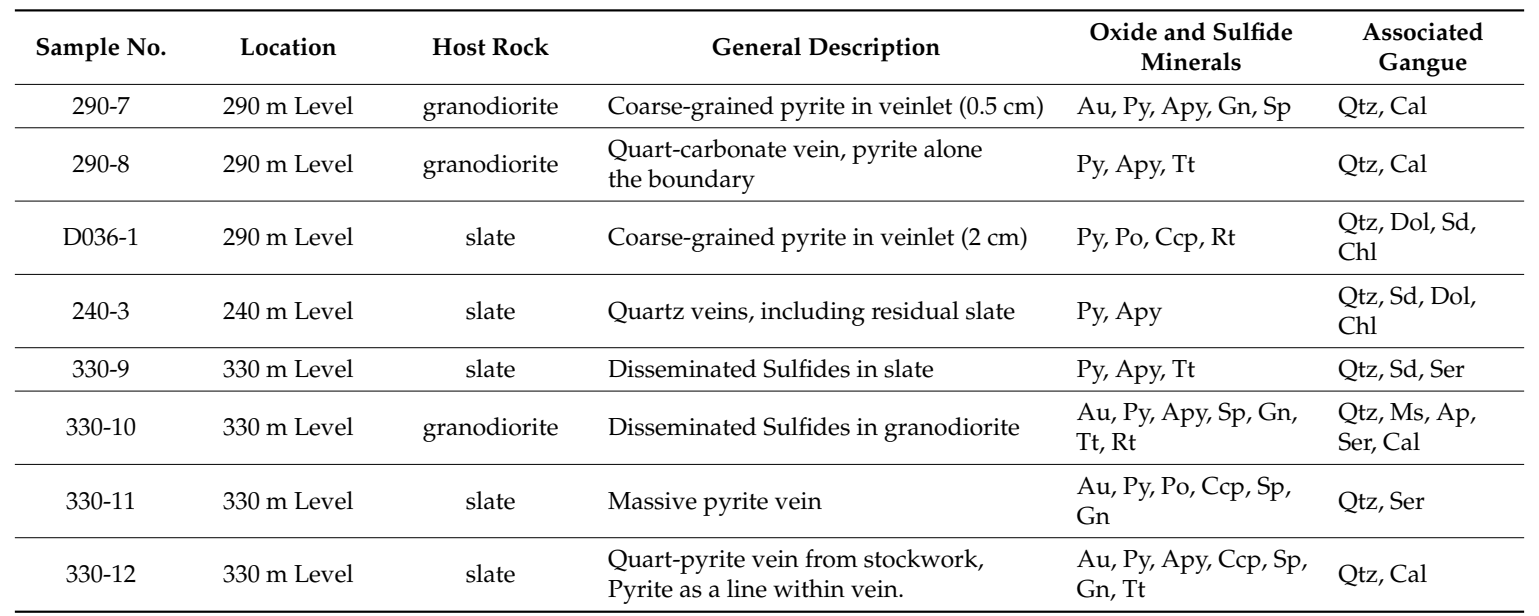

Abreviations: $\mathrm{Au}$ —native gold; $\mathrm{Py}$-pyrite; Asp—arsenopyrite; $\mathrm{Ccp}$-chalcopyrite; $\mathrm{Gn}$-galena; Sp—sphalerite; Po-pyrrhotite; Tt—-tetrahedrite; Rt—rutile; Qtz-quartz; Cal—carbonate; Sd-siderite; Dol—dolomite; Ser-sericite; Ms—muscovite; Chl—chlorite; Ap—apatite.

\subsection{Electron-Probe Microanalyses}

Ore minerals and ore textures were observed in polished sections using standard reflected-light microscopy techniques. Selected representative thin sections containing more auriferous pyrite and Au-bearing minerals were analyzed by electron probe microanalysis (EPMA) using a Shimadzu EPMA-1720H housed at the School of Geosciences and Info-physics (SGI), Central South University (CSU), Changsha, China. The operating conditions of the electron microprobe maintained an accelerating voltage of $15 \mathrm{kV}$, a beam current of $10 \mathrm{nA}$, and an electron beam diameter of $1 \mu \mathrm{m}$. The following X-ray lines were used to analyze different elements: AsL, SK, FeK, CoK, NiK, AuM, and $\mathrm{PbM}$. The mineral and metal standards used for the calibration of elemental X-ray intensities included pyrite ( $\mathrm{S}$ and $\mathrm{Fe})$, gallium arsenide $(\mathrm{As})$, cobalt $(\mathrm{Co})$, nickel $(\mathrm{Ni})$, gold $(\mathrm{Au})$ and galena $(\mathrm{Pb})$. The resulting data were then ZAF-corrected using proprietary Shimadzu software. The minimum detection limit of Co was $0.03 \mathrm{wt} \%$, that of $\mathrm{Ni}$ was $0.01 \mathrm{wt} \%$, that of Au was $0.06 \mathrm{wt} \%$, that of $\mathrm{Pb}$ was $0.04 \mathrm{wt} \%$.

To understand the distribution of the main elements in auriferous pyrite, EPMA X-ray elemental maps were obtained from representative grains.

\subsection{LA-ICP-MS Analysis}

The analytical instrumentation employed in this study consists of a New Wave UP-213 nm Laser Ablation System coupled with an Agilent 7700s Quadrupole ICP-MS housed in the CODES LA-ICP-MS facility at the University of Tasmania, Hobart, Australia. Depending on the size of the pyrite grain, analyses were performed by laser ablation using spot diameters of $10-35 \mu \mathrm{m}$ and a repetition rate of $2-5 \mathrm{~Hz}$. The laser beam energy was maintained between 1.6 and $2.5 \mathrm{~J} / \mathrm{cm}^{2}$. The analysis time for each sample was $90 \mathrm{~s}$, including $30 \mathrm{~s}$ of background measurement with the laser off and $60 \mathrm{~s}$ of 
analysis with the laser on. The acquisition time for all masses was set to $0.02 \mathrm{~s}$, with a total sweep time of $\sim 0.6 \mathrm{~s}$. Data reduction was performed using standard methods $[43,44]$, with Fe as the internal standard. Calibration was performed using the in-house standard (STDGL2b-2), which comprises powdered sulfides doped with certified element solutions and fused to a lithium borate glass disk [45]. The standard was analyzed twice every $1.5 \mathrm{~h}$ with a $100-\mu \mathrm{m}$ beam size at $10 \mathrm{~Hz}$ to correct for instrument drift. The accuracy is expected to be better than $20 \%$ for most elements [45]. A series of 28 elements was chosen for spot analysis (i.e., Al, Ti, V, Cr, Mn, Fe, Co, Ni, Cu, Zn, As, Se, Zr, Mo, Ag, Sn, Sb, Te, Ba, $\mathrm{La}, \mathrm{W}, \mathrm{Pt}, \mathrm{Au}, \mathrm{Tl}, \mathrm{Pb}, \mathrm{Bi}$, Th, and $\mathrm{U}$ ) in this study. The minimum detection limit of $\mathrm{S}$ was $50.8176 \mathrm{ppm}$, that of Fe was $2.9364 \mathrm{ppm}$, that of As was $0.8589 \mathrm{ppm}$, that of Au was $0.0009 \mathrm{ppm}$, that of Co was $0.0035 \mathrm{ppm}$, that of $\mathrm{Ni}$ was $0.003 \mathrm{ppm}$, that of $\mathrm{Cu}$ was $0.0738 \mathrm{ppm}$, that of $\mathrm{Zn}$ was $0.1571 \mathrm{ppm}$, that of $\mathrm{Pb}$ was $0.0059 \mathrm{ppm}$, that of Ag was $0.0099 \mathrm{ppm}$, that of Se was $2.4309 \mathrm{ppm}$, that of Te was $0.039 \mathrm{ppm}$, that of $\mathrm{Sb}$ was $0.0223 \mathrm{ppm}$, that of $\mathrm{Bi}$ was $0.0005 \mathrm{ppm}$.

\section{Results}

\subsection{Petrography and Mineralogy}

The ore minerals are mainly composed of pyrite and arsenopyrite; lesser amounts of galena, sphalerite, chalcopyrite, tetrahedrite, pyrrhotite, rutile and native gold formed during stage II and stage III (Figure 6). The gangue minerals include quartz, carbonate (i.e., dolomite, siderite, calcite), sericite, and chlorite (Figure 4).

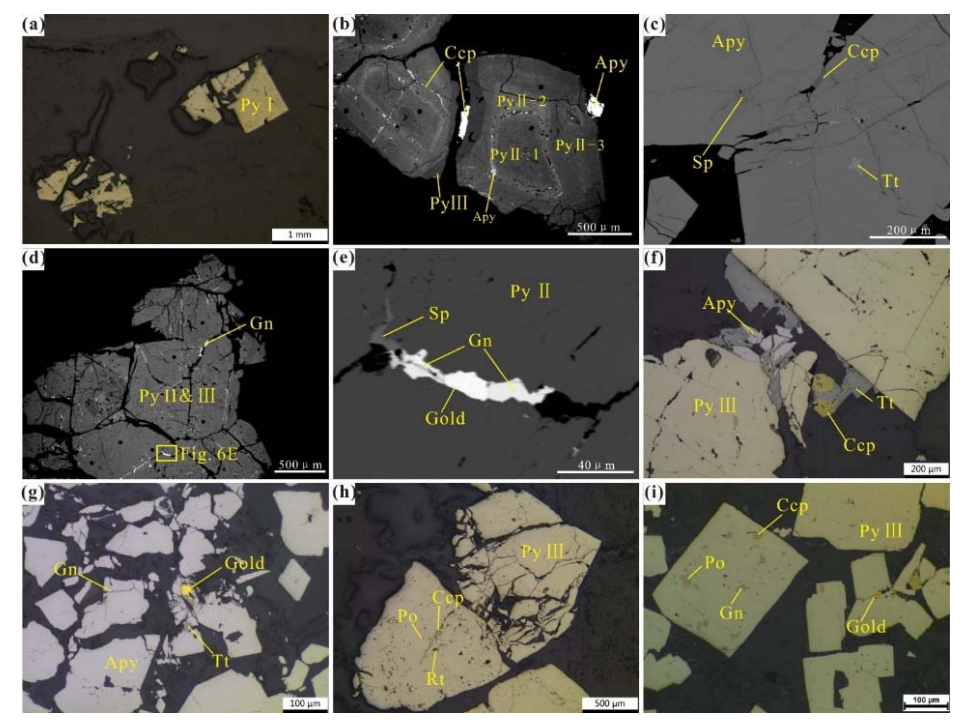

Figure 6. Photomicrographs showing textures and features of metal minerals in Zhengchong gold deposit: (a) Reflected light image of isolated gold-barren PyI showing a fractured or corroded pyrite crystal. (b) BSE image of oscillatory zonation of PyII; lighter bands are As-rich. Arsenopyrite and tetrahedrite occur in pores of PyII-2. Chalcopyrite fills the fractures of PyII or occurs as overgrowth on PyIII in a quartz-carbonate vein. (c) BSE image of chalcopyrite and sphalerite cross-cutting arsenopyrite. (d) BSE image of galena filling the fracture of cataclastic pyrite. Sample 290-7 is from a large pyrite crystal in a veinlet. (e) Detail of minerals in fracture in Figure $4 \mathrm{~d}$ showing the intergrowth of native gold, galena and sphalerite in fracture. $(\mathbf{f}, \mathbf{g})$ Earlier-formed chalcopyrite and pyrite, overgrowth of arsenopyrite, tetrahedrite wrapping native gold, and galena finally filling the fracture in a disseminated pyrite vein in stockwork. (h) Galena, pyrrhotite, and chalcopyrite occurring as inclusions in PyIII from a large pyrite pebble in veinlet shown in Figure 3f. (i) Euhedral PyIII with significant amounts of native gold, galena, chalcopyrite and pyrrhotite inclusions in a massive pyrite vein. Py—pyrite; Asp—arsenopyrite; Ccp—chalcopyrite; Gn—galena; Sp—sphalerite; Po—pyrrhotite; Rt-rutile; Gold-visible native gold; $\mathrm{Tt}$ - tetrahedrite. 
Pyrite is a very common mineral in most metamorphosed ore deposits and many types of metamorphic rocks [26]. Once pyrite has formed, it becomes much more refractory and retains many of its characteristics, even in deposits that have undergone penetrative deformation [26]. The pyrite in the Zhengchong gold deposit, which is the most abundant sulfide in these orebodies, is entirely hydrothermal pyrite. Three major crystal growth stages were defined based on their textures and paragenetic sequences observed using optical microscopy and back-scattered electron (BSE) images obtained by EMPA (Figure 6). PyI is characterized by isolated crystals in quartz veins (Figure 6a) or disseminated euhedral to subhedral cubes in country rock ( 1 mm across). PyII comprises euhedral to subhedral cubic crystals ( $500 \mu \mathrm{m}$ across); these grains exhibit oscillatory zonation with core-rim structures and are commonly overprinted by other minerals (Figure $6 \mathrm{~b}, \mathrm{~d}$ ). Three subgenerations (PyII-1, -2, -3) were defined based on BSE images (Figure 6b), and the pores of PyII-2 commonly contain arsenopyrite and tetrahedrite. PyIII, which comprises euhedral and subhedral cubes $(100 \mu \mathrm{m} \sim 1 \mathrm{~mm}$ across), is characterized by inclusions (e.g., gold, chalcopyrite, galena, sphalerite and pyrrhotite) (Figure 6f,h,i).

\subsection{EPMA Data}

The EMPA data obtained from different generations of pyrite are listed in Table 2. Point analyses were obtained from the core to the rim on relatively large pyrite grains. The average $\mathrm{Fe}, \mathrm{S}$ and $\mathrm{As}$ contents are $47.18 \mathrm{wt} \%, 53.74 \mathrm{wt} \%$ and $0.37 \mathrm{wt} \%$ for PyI; $46.96 \mathrm{wt} \%, 52.73 \mathrm{wt} \%$ and $1.49 \mathrm{wt} \%$ for PyII-1; $46.40 \mathrm{wt} \%, 51.58 \mathrm{wt} \%$ and $3.01 \mathrm{wt} \%$ for PyII-2; $46.90 \mathrm{wt} \%, 52.48 \mathrm{wt} \%$ and $1.63 \mathrm{wt} \%$ for PyII-3; and $46.72 \mathrm{wt} \%$, and $52.34 \mathrm{wt} \%$ and $1.72 \mathrm{wt} \%$ for PyIII, respectively. The concentrations of $\mathrm{Au}$ and other trace elements $(\mathrm{Co}, \mathrm{Ni}, \mathrm{Pb})$ in pyrite were close to or below the limits of detection.

Table 2. Selected EPMA analyses of different generations of pyrite from the Zhengchong deposit (wt \%).

\begin{tabular}{ccccccccc}
\hline Pyrite Type & & As & S & Fe & Co & Ni & Au & Pb \\
\hline PyI & Min. & 0.20 & 52.60 & 46.77 & 0.03 & 0.02 & 0.06 & 0.05 \\
& Max. & 1.12 & 54.32 & 47.80 & 0.07 & 0.08 & 0.11 & 0.24 \\
& SD & 0.34 & 0.57 & 0.35 & 0.02 & 0.02 & 0.03 & 0.07 \\
\multirow{2}{*}{ PyII-1 } & Av. & 0.37 & 53.74 & 47.18 & 0.05 & 0.03 & 0.08 & 0.14 \\
& Min. & 1.01 & 52.43 & 46.64 & 0.04 & 0.02 & 0.08 & 0.05 \\
& Max. & 1.95 & 53.22 & 47.21 & 0.12 & 0.08 & 0.16 & 0.12 \\
$n=7$ & SD & 0.36 & 0.29 & 0.24 & 0.03 & 0.03 & 0.06 & 0.03 \\
PyII-2 & Av. & 1.49 & 52.73 & 46.96 & 0.07 & 0.04 & 0.12 & 0.09 \\
& Min. & 2.51 & 50.60 & 45.70 & 0.04 & 0.02 & 0.15 & 0.04 \\
& Max. & 4.19 & 51.96 & 47.00 & 0.08 & 0.08 & 0.15 & 0.20 \\
\multirow{2}{*}{$n=7$} & SD & 0.56 & 0.46 & 0.40 & 0.02 & 0.03 & & 0.05 \\
PyII-3 & Av. & 3.01 & 51.58 & 46.40 & 0.06 & 0.05 & 0.15 & 0.10 \\
& Min. & 1.23 & 52.12 & 46.55 & 0.04 & 0.04 & & 0.05 \\
& Max. & 2.12 & 53.10 & 47.46 & 0.09 & 0.04 & & 0.31 \\
$n=7$ & SD & 0.34 & 0.37 & 0.30 & 0.02 & & & 0.10 \\
PyIII & Av. & 1.63 & 52.48 & 46.90 & 0.06 & 0.04 & & 0.11 \\
& Min. & 1.09 & 50.13 & 46.03 & 0.03 & 0.01 & 0.07 & 0.04 \\
& Max. & 3.18 & 53.37 & 47.35 & 0.14 & 0.15 & 0.12 & 0.20 \\
$n=15$ & SD & 0.52 & 0.75 & 0.38 & 0.03 & 0.05 & 0.02 & 0.05 \\
& Av. & 1.72 & 52.34 & 46.72 & 0.06 & 0.06 & 0.10 & 0.11 \\
\hline
\end{tabular}

Arsenic, cobalt and nickel contents can be mapped using EMPA to interpret the crystallization processes of pyrite [26]. PyI shows no discernible pattern in terms of the distribution of cobalt and nickel, but arsenic and sulfur show a visible negative correlation (Figure 7). PyII displays well-developed primary crystallographic growth bands (Figures 8 and 9) through the maps of Co, Ni and As, as well as the clearly visible core of a preexisting pyrite (Figure 8). PyIII shows low contents and 
uniform distributions of $\mathrm{Co}, \mathrm{Ni}$, and As, with inclusions of galena, chalcopyrite, sphalerite, pyrrhotite and gold (Figures 9 and 10), only the outer of PyIII is characterized by well-developed arsenic, cobalt and nickel zoning (Figure $10 \mathrm{~b}-\mathrm{d}$ ). The correlation of element anomalies in one large fractured crystal reflects the replacement and characteristics of the distribution of elements between PyII and PyIII (Figure 9).
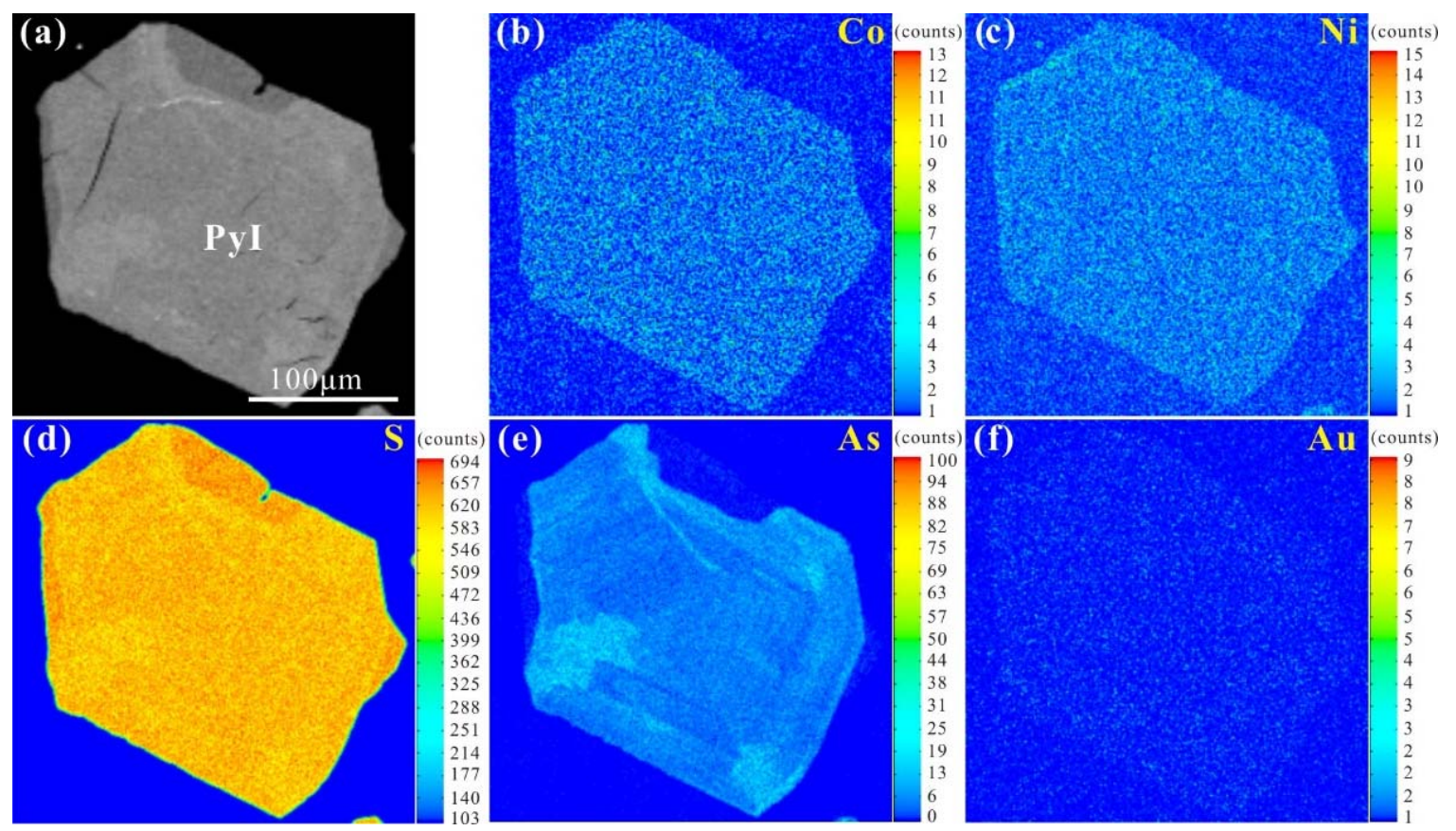

Figure 7. (a) Backscattered electron image of PyI from sample 330-9. (b-f) X-ray element distribution maps of Co, Ni, S, As, and Au in PyI. Cobalt and nickel show uniform distribution, but irregular arsenic enrichment occurs in isolated crystal PyI.
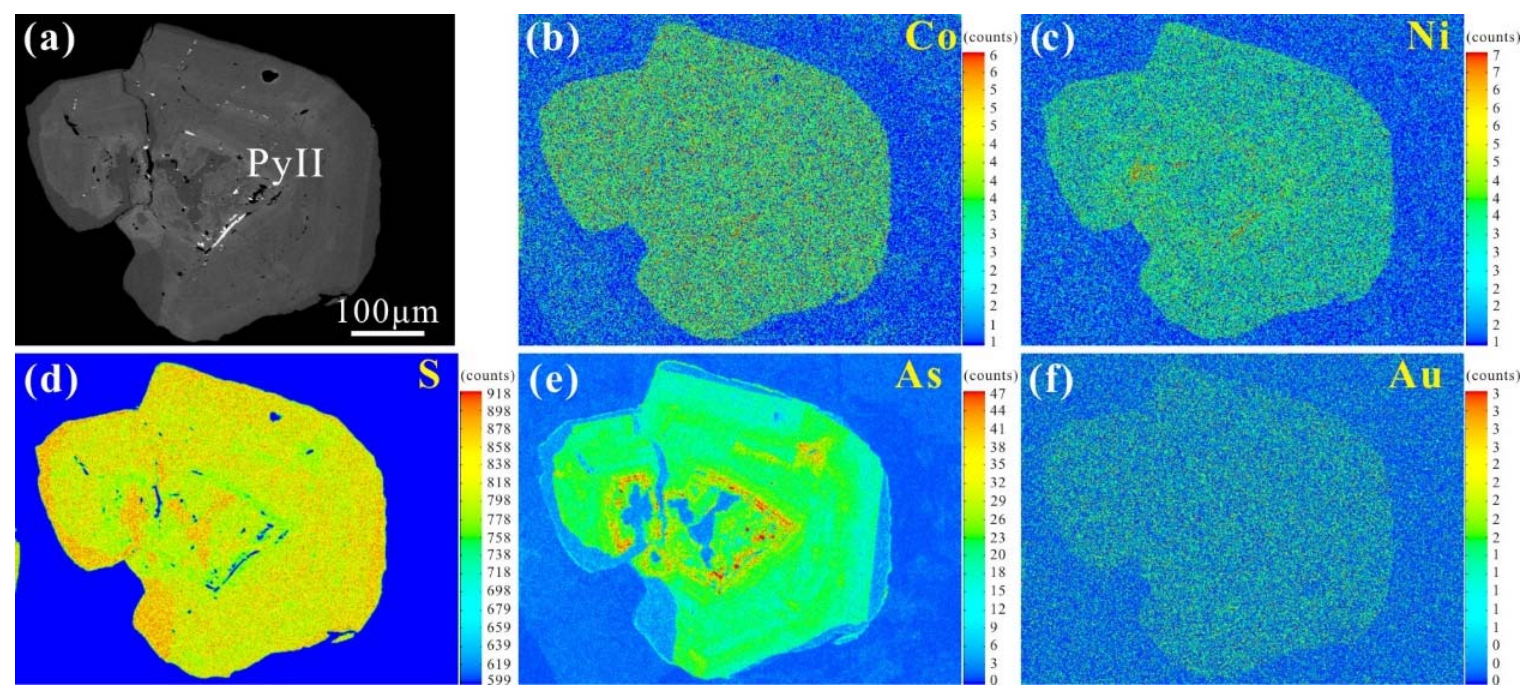

Figure 8. (a) Backscattered electron image of PyII from sample 290-8. (b-f) X-ray element distribution maps of $\mathrm{Co}, \mathrm{Ni}, \mathrm{S}, \mathrm{As}$, and $\mathrm{Au}$ in PyII. PyII contains weakly visible growth zoning indicating that cobalt, nickel and arsenic are present in similar concentric zones in these crystals. 

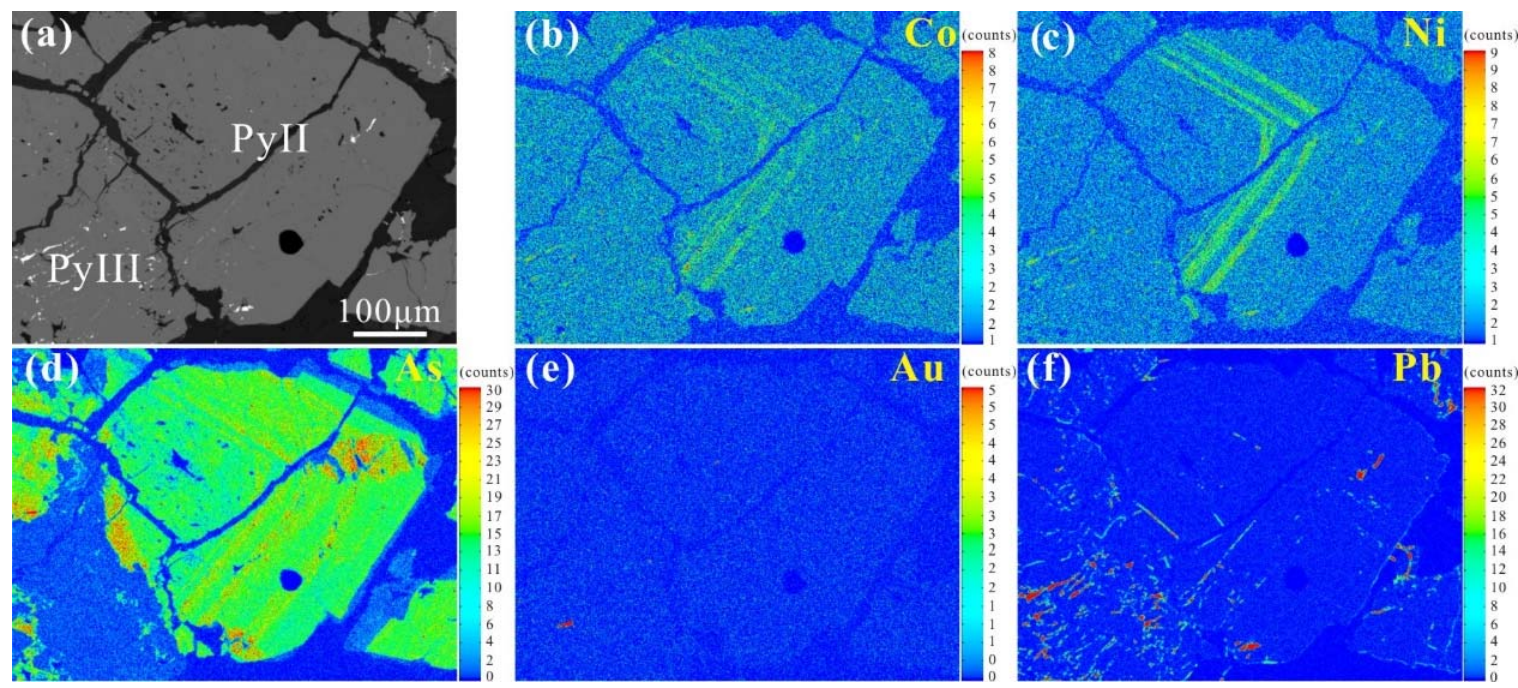

Figure 9. (a) Backscattered electron image of PyII and PyIII from sample 290-7. (b-f) X-ray element distribution maps of $\mathrm{Co}, \mathrm{Ni}, \mathrm{As}, \mathrm{Au}$, and $\mathrm{Pb}$ in PyII and PyIII. PyIII replace cataclastic PyII, as shown in Figure 6d.
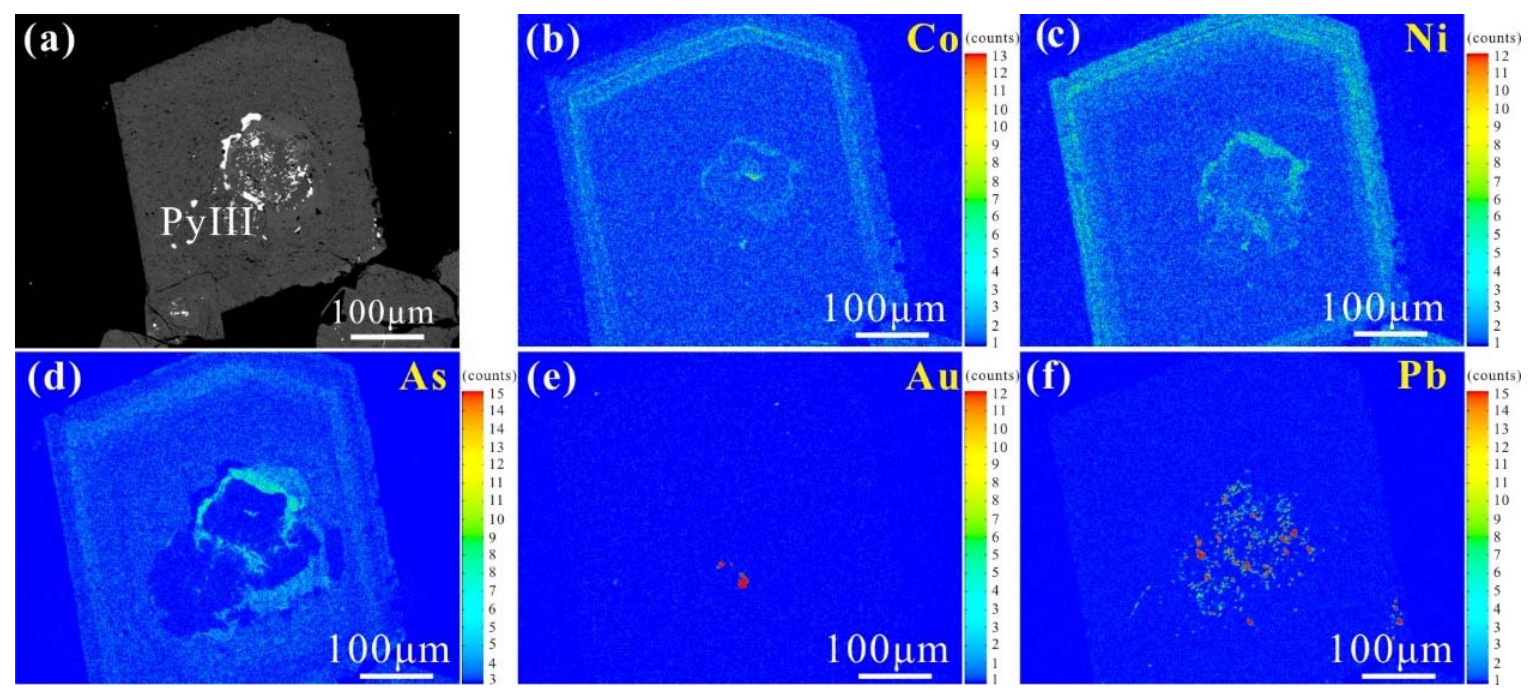

Figure 10. (a) Backscattered electron image of PyIII from sample 330-11. (b-f) X-ray element distribution maps of $\mathrm{Co}, \mathrm{Ni}, \mathrm{As}, \mathrm{Au}$, and $\mathrm{Pb}$ in PyIII. The inclusion-rich PyIII contains inclusions of galena, sphalerite, chalcopyrite, tetrahedrite, pyrrhotite and native gold; the distributions of As, Co, and $\mathrm{Ni}$ are heterogeneous in inter; oscillatory zonation is present in outer; and the distributions of $\mathrm{Au}$ and $\mathrm{Pb}$ are present in inclusions.

\subsection{Trace Element Contents in Pyrites}

A total of 36 LA-ICP-MS spot analyses were completed on pyrites selected from two typical samples $(290-7,290-8)$ in the Zhengchong gold deposit (Table 3); these analyses included 4 analyses of PyI, 20 analyses of PyII and 12 analyses of PyIII. 
Table 3. Selected LA-ICP-MS analyses of different generations of pyrite from the Zhengchong deposit.

\begin{tabular}{|c|c|c|c|c|c|c|c|c|c|c|c|c|c|c|c|c|c|}
\hline $\begin{array}{l}\text { Pyrite } \\
\text { Type }\end{array}$ & & $\begin{array}{c}\text { S, As, Se } \\
\text { (wt \%) }\end{array}$ & $\begin{array}{c}\mathrm{Fe} \\
(w t \%)\end{array}$ & $\begin{array}{c}\text { As } \\
\text { (ppm) }\end{array}$ & $\begin{array}{c}\mathrm{Au} \\
(\mathrm{ppm})\end{array}$ & $\begin{array}{c}\text { Co } \\
\text { (ppm) }\end{array}$ & $\begin{array}{c}\mathrm{Ni} \\
(\mathrm{ppm})\end{array}$ & $\begin{array}{c}\mathrm{Cu} \\
(\mathrm{ppm})\end{array}$ & $\begin{array}{c}\mathrm{Zn} \\
(\mathrm{ppm})\end{array}$ & $\begin{array}{c}\mathrm{Pb} \\
(\mathrm{ppm})\end{array}$ & $\begin{array}{c}\mathrm{Ag} \\
(\mathrm{ppm})\end{array}$ & $\begin{array}{c}\text { Se } \\
\text { (ppm) }\end{array}$ & $\begin{array}{c}\mathrm{Te} \\
\text { (ppm) }\end{array}$ & $\begin{array}{c}\mathrm{Sb} \\
(\mathrm{ppm})\end{array}$ & $\begin{array}{c}\mathbf{B i} \\
\text { (ppm) }\end{array}$ & $\mathrm{Co} / \mathrm{Ni}$ & $\mathrm{Se} / \mathrm{Te}$ \\
\hline \multirow[t]{3}{*}{ PyI } & Min. & 52.94 & 46.33 & 183.04 & 0.02 & 0.00 & 0.02 & 0.55 & 0.53 & 0.10 & 0.02 & 3.72 & 0.05 & 0.04 & 0.03 & 0.01 & 33.74 \\
\hline & Max. & 53.37 & 46.52 & 6869.63 & 0.86 & 0.92 & 6.55 & 300.61 & 1241.20 & 552.96 & 0.57 & 17.13 & 0.51 & 25.60 & 19.57 & 0.32 & 107.37 \\
\hline & SD & 0.21 & 0.08 & 3501.40 & 0.36 & 0.47 & 3.45 & 149.70 & 620.13 & 265.99 & 0.26 & 5.66 & 0.21 & 12.08 & 9.24 & 0.13 & 30.19 \\
\hline$n=4$ & Av. & 53.14 & 46.39 & 3647.71 & 0.53 & 0.40 & 3.18 & 76.06 & 311.00 & 214.99 & 0.22 & 9.63 & 0.19 & 7.65 & 6.08 & 0.15 & 72.08 \\
\hline \multirow[t]{3}{*}{ PyII-1 } & Min. & 51.84 & 45.95 & $11,324.34$ & 2.35 & 0.01 & 0.16 & 1.64 & 0.21 & 6.72 & 0.03 & 4.42 & 0.07 & 0.80 & 0.12 & 0.05 & 40.50 \\
\hline & Max. & 52.62 & 46.23 & $21,855.37$ & 26.72 & 22.20 & 125.99 & 16.68 & 0.57 & 231.59 & 0.21 & 36.99 & 0.91 & 20.74 & 6.66 & 0.22 & 144.50 \\
\hline & SD & 0.33 & 0.12 & 4554.95 & 8.41 & 9.35 & 48.17 & 5.68 & 0.13 & 80.96 & 0.07 & 10.67 & 0.32 & 6.88 & 2.36 & 0.06 & 41.08 \\
\hline$n=6$ & Av. & 52.20 & 46.08 & $16,986.38$ & 11.91 & 7.48 & 60.62 & 10.20 & 0.40 & 91.81 & 0.07 & 18.66 & 0.27 & 7.45 & 2.30 & 0.12 & 94.67 \\
\hline \multirow[t]{3}{*}{ PyII-2 } & Min. & 50.82 & 45.54 & $22,663.61$ & 24.67 & 17.13 & 97.02 & 30.44 & 0.48 & 74.44 & 0.06 & 9.68 & 0.19 & 2.40 & 1.56 & 0.18 & 14.13 \\
\hline & Max. & 51.78 & 45.93 & $35,709.79$ & 56.51 & 98.69 & 371.70 & 54.59 & 1.00 & 319.26 & 0.17 & 15.66 & 0.70 & 22.17 & 6.63 & 0.27 & 50.48 \\
\hline & $\mathrm{SD}$ & 0.48 & 0.19 & 6523.10 & 16.54 & 42.02 & 138.26 & 12.10 & 0.28 & 136.70 & 0.06 & 2.99 & 0.26 & 10.35 & 2.76 & 0.05 & 14.13 \\
\hline$n=3$ & Av. & 51.30 & 45.73 & 29,191.95 & 38.01 & 52.07 & 225.19 & 42.98 & 0.68 & 161.72 & 0.12 & 12.62 & 0.41 & 10.51 & 3.47 & 0.21 & 36.86 \\
\hline \multirow[t]{3}{*}{ PyII-3 } & Min. & 51.52 & 45.83 & $15,167.92$ & 3.69 & 0.01 & 0.20 & 1.99 & 0.26 & 1.54 & 0.02 & 2.9 & 0.04 & 0.59 & 0.14 & 0.04 & 26.97 \\
\hline & Max. & 52.34 & 46.14 & $26,128.99$ & 19.44 & 67.41 & 411.14 & 83.87 & 0.83 & 762.91 & 0.43 & 7.73 & 0.29 & 31.84 & 10.05 & 0.55 & 75.62 \\
\hline & SD & 0.20 & 0.08 & 2730.29 & 5.13 & 20.67 & 125.76 & 23.89 & 0.19 & 242.90 & 0.15 & 1.37 & 0.07 & 9.69 & 3.11 & 0.16 & 13.41 \\
\hline$n=10$ & Av. & 51.92 & 45.98 & $20,838.69$ & 9.50 & 8.92 & 57.01 & 18.01 & 0.44 & 162.75 & 0.13 & 4.97 & 0.11 & 10.38 & 3.10 & 0.20 & 51.16 \\
\hline \multirow[t]{3}{*}{ PyIII } & Min. & 51.58 & 45.62 & 8862.14 & 2.66 & 2.40 & 7.67 & 2.62 & 0.19 & 0.31 & 0.01 & 28.40 & 1.22 & 0.05 & 0.06 & 0.26 & 2.10 \\
\hline & Max. & 52.79 & 46.30 & $20,429.36$ & 35.58 & 1083.30 & 2599.41 & 32.55 & 4.31 & 644.37 & 0.39 & 97.17 & 46.28 & 36.83 & 9.75 & 0.67 & 23.23 \\
\hline & SD & 0.31 & 0.21 & 3447.75 & 9.60 & 316.16 & 782.05 & 9.42 & 1.15 & 202.70 & 0.14 & 19.62 & 12.88 & 10.22 & 3.29 & 0.10 & 5.82 \\
\hline$n=12$ & Av. & 52.24 & 46.03 & $15,870.44$ & 15.92 & 164.57 & 444.62 & 11.87 & 0.67 & 159.95 & 0.13 & 66.97 & 20.80 & 8.49 & 3.01 & 0.37 & 5.31 \\
\hline
\end{tabular}


PyI contains low $\mathrm{Au}(<1 \mathrm{ppm})$ and As $(183 \sim 6870 \mathrm{ppm})$ contents, as well as low contents of the following trace elements: Co (<1 ppm), Ni (<7 ppm), Cu (0.5-301 ppm), Zn (0.5 1241 ppm), $\mathrm{Pb}(0.1 \sim 553 \mathrm{ppm}), \mathrm{Ag}(5.4 \sim 28 \mathrm{ppm}), \mathrm{Se}(4 \sim 17 \mathrm{ppm}), \mathrm{Sb}$ (1 26 ppm), Te (<1 ppm), and Bi (0.03 $20 \mathrm{ppm})$.

PyII records relatively higher abundances of $\mathrm{Au}(2 \sim 57 \mathrm{ppm})$, As $(11,324 \sim 35,710 \mathrm{ppm})$, $\mathrm{Cu}(2 \sim 84 \mathrm{ppm})$, and $\mathrm{Bi}(0.1 \sim 10 \mathrm{ppm})$, as well as the following concentrations of other trace elements: Co (0.01 99 ppm), Ni (0.1 411 ppm), Zn (<1 ppm), Pb (3 763 ppm), Ag (<1 ppm), Se (3 37 ppm), $\mathrm{Sb}(0.5 \sim 32 \mathrm{ppm})$, and Te (<1 ppm).

Compared to PyII (Figure 11), PyIII is enriched in Au (2.5 36 ppm), Co (2 1083 ppm), $\mathrm{Ni}(7.6 \sim 2599 \mathrm{ppm}), \mathrm{Te}$ (1.2 46 ppm), and Se (28 97 ppm); the other trace elements measured in PyIII include $\mathrm{Cu}(2.6 \sim 33 \mathrm{ppm}), \mathrm{Zn}(0.1 \sim 4.3 \mathrm{ppm}), \mathrm{Pb}(0.3 \sim 644 \mathrm{ppm}), \mathrm{Ag}(<1 \mathrm{ppm}), \mathrm{As}(8862 \sim 20429 \mathrm{ppm})$, $\mathrm{Sb}(0.05 \sim 37 \mathrm{ppm})$, and Bi (0.06 10 ppm).

These As concentrations are generally consistent with those determined by EPMA (Tables 2 and 3). Differences in As were observed between different types of pyrite.

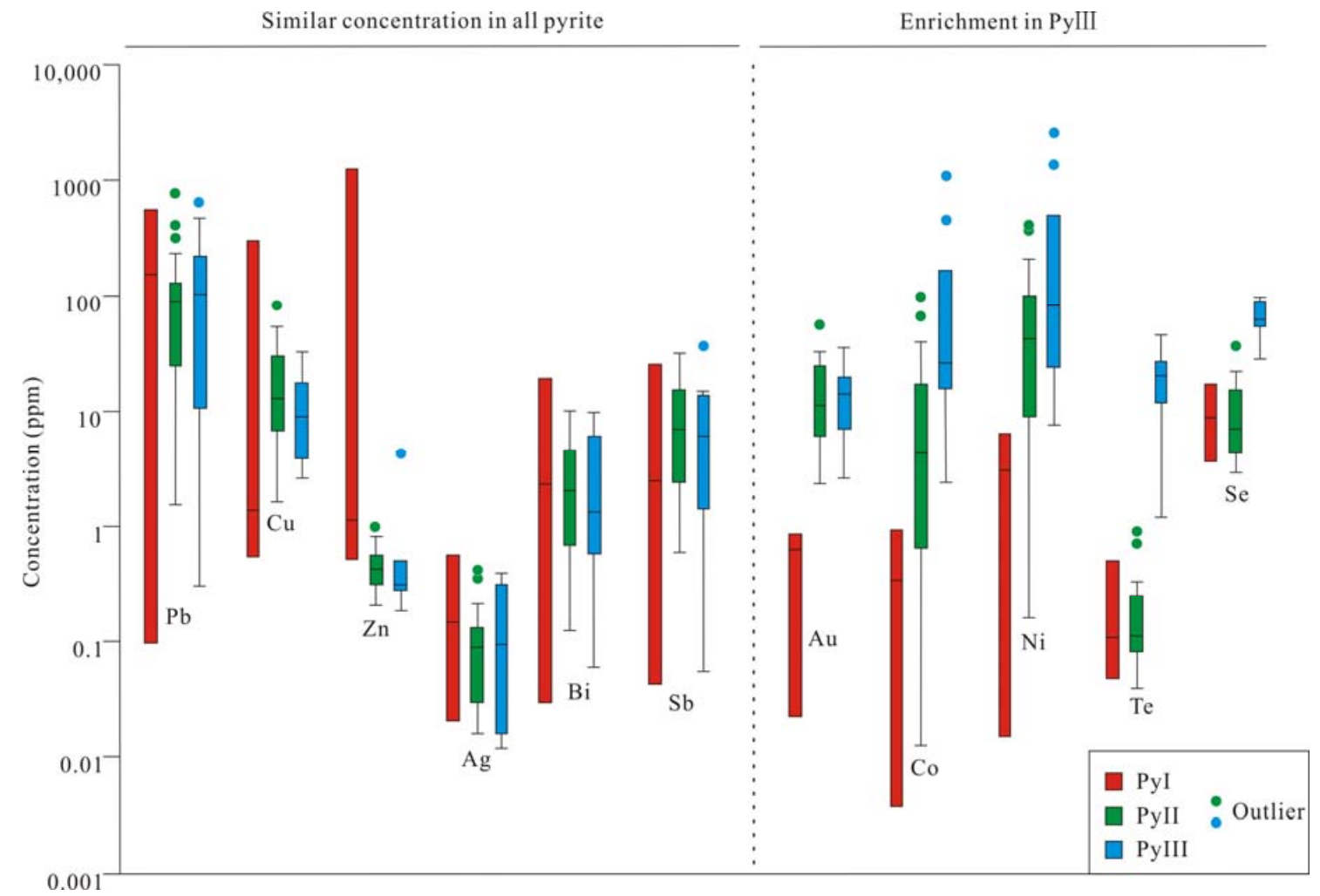

Figure 11. Comparative box plot of the LA-ICP-MS data of three generations of pyrite, illustrating the concentration ranges of specific trace elements and highlighting significant relative enrichments. The red box indicate PyI, the green box present PyII, and the blue box shows PyIII. The outlier present the anomalous data, error bars represent SD.

Pyrite can be subdivided into three group, which are consistent with the ore forming stage (Figure 11). PyI contains low $\mathrm{Au}, \mathrm{As} \mathrm{Co}$, Ni contents, but a large ranges in concentrations of $\mathrm{Pb}, \mathrm{Cu}, \mathrm{Zn}$, $\mathrm{Bi}$, Sb due to the presence of inclusions (Figure 12a). PyII and PyIII record relatively higher abundances of $\mathrm{Au}$, As, but PyIII more enrich $\mathrm{Co}, \mathrm{Ni}, \mathrm{Se}, \mathrm{Te}$, sometimes the content of $\mathrm{Pb}$ in PyII and PyIII is really high due to the presence of inclusions (Figure 12b). 


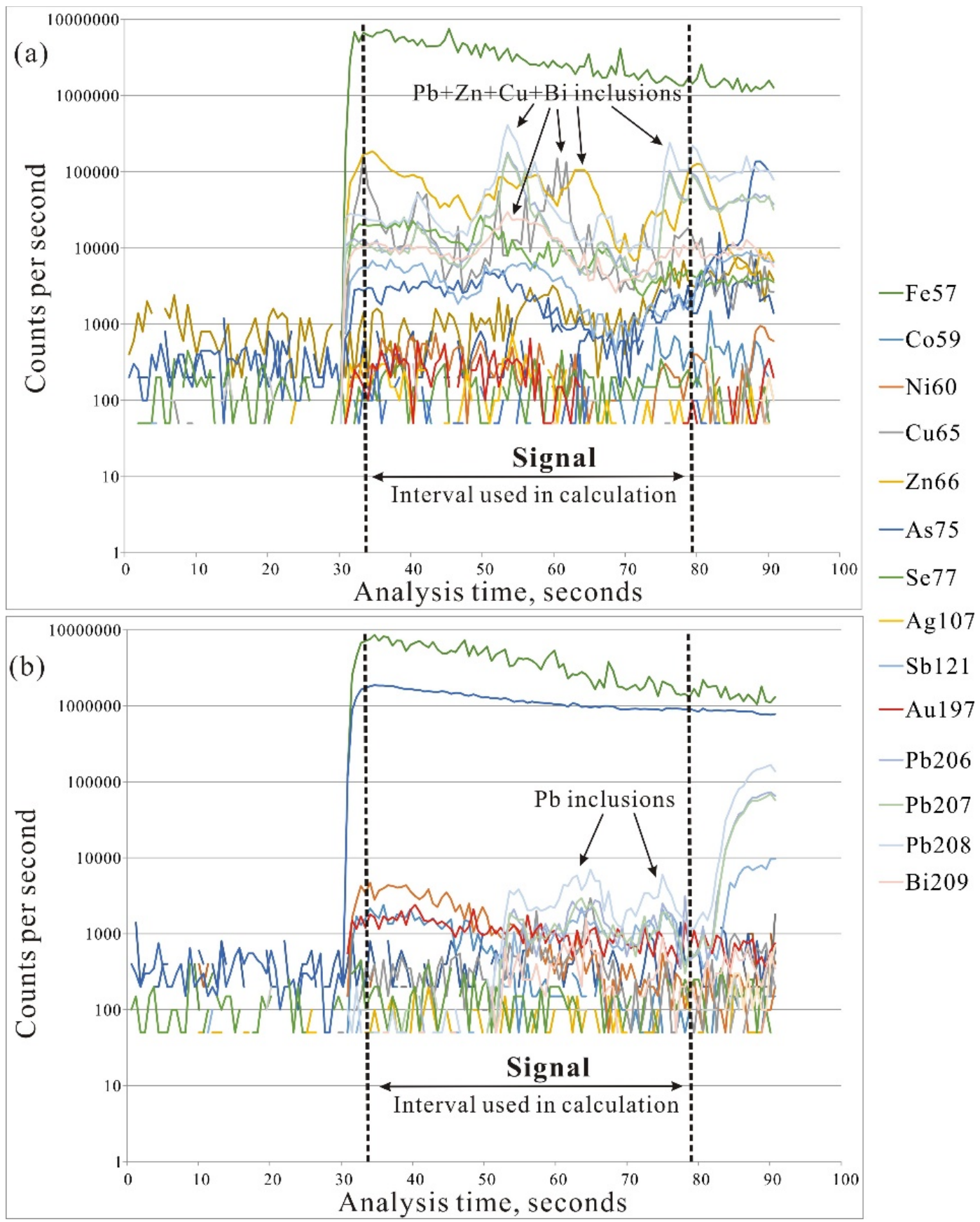

Figure 12. Time-resolved record of the signal recorded on the LA-ICP-MS (in counts per second) during a single analysis. (a) PyI-low $\mathrm{Au}$ and $\mathrm{As}$, but $\mathrm{Pb}+\mathrm{Zn}+\mathrm{Cu}$ and Bi-bearing inclusions; (b) PyII-high contents of $\mathrm{Au}, \mathrm{As}, \mathrm{Ni}$, and $\mathrm{Pb}$-bearing inclusion.

\section{Discussion}

\subsection{Distribution and Correlations of Trace Elements in Pyrites}

The trace element concentrations in pyrite depend on both the nature of the ore fluid and the geochemical properties of the elements. Therefore, trace elements in pyrite have been widely used to constrain the characteristics of ore fluid [18,46-48]. The correlations between selected major and trace elements in these pyrites are shown in Figure 13. 

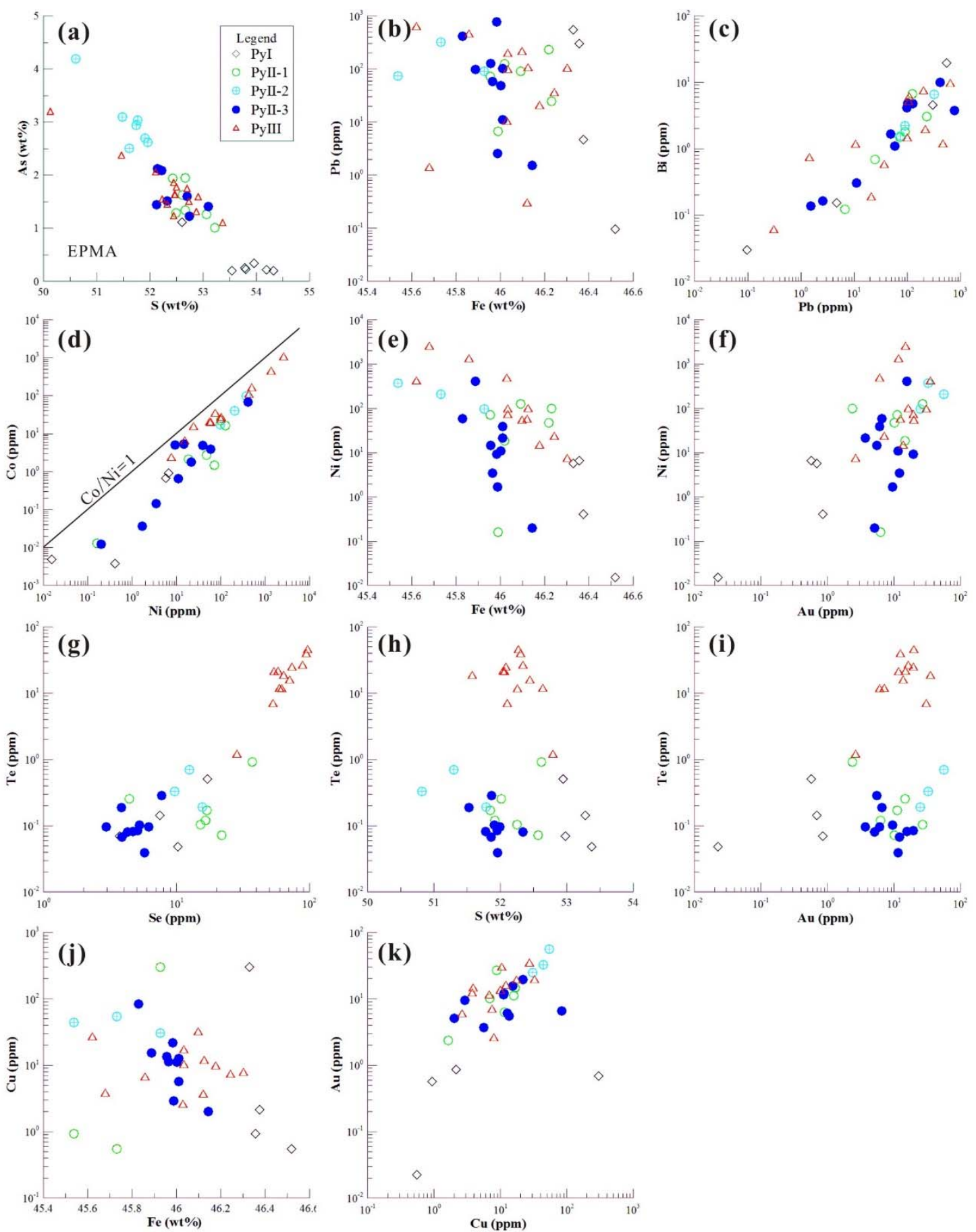

Figure 13. Binary plots of selected elements in different generations of pyrite from the Zhengchong gold deposit. (a) S and As data are from Table 2. Correlation between other elements from Table 3: (b) plot of Fe vs. $\mathrm{Pb}$; (c) plot of $\mathrm{Pb}$ vs. $\mathrm{Bi}$; (d) plot of $\mathrm{Ni}$ vs. $\mathrm{Co}$; (e) plot of $\mathrm{Fe}$ vs. Ni; (f) plot of $\mathrm{Au}$ vs. Ni; (g) plot of Se vs. Te; (h) plot of $\mathrm{S}$ vs. Te; (i) plot of Au vs. Te; (j) plot of Fe vs. Cu; (k) plot of Cu vs. Au.

The EPMA results reveal that nearly all pyrite samples contain significant amounts of As, as well as a wide range of other trace elements, such as $\mathrm{Au}, \mathrm{Co}, \mathrm{Ni}$, and $\mathrm{Pb}$. PyI contains lower $\mathrm{As}$ contents; in contrast, PyII and PyIII-2 record higher As contents (i.e., up to wt \% levels), and these pyrites can thus be classified as arsenian pyrite. However, only PyIII is associated with native gold. The EPMA results show a well-defined negative correlation between As and S (Figure 13a), which 
is consistent with the substitution of $\mathrm{As}$ for $\mathrm{S}$ as anionic $\mathrm{As}^{-}$in the $\mathrm{Fe}\left(\mathrm{S}_{1-\mathrm{x}} \mathrm{As} \mathrm{s}_{\mathrm{x}}\right)_{2}$ solid solution in reducing environments $[49,50]$.

There is no clear relationship between $\mathrm{Pb}$ and $\mathrm{Fe}$ (Figure 13b), and a positive correlation was observed between $\mathrm{Bi}$ and $\mathrm{Pb}$ in pyrite (Figure 13c). Therefore, we speculate that most of the $\mathrm{Pb}$ distributed in pyrite comprises galena inclusions and that Bi occurs as a solid solution in galena (Figure 12) [51].

A well-defined positive correlation exists between $\mathrm{Co}$ and $\mathrm{Ni}$ (Figure 13d), and a negative correlation exists between $\mathrm{Ni}$ and $\mathrm{Fe}$ (Figure 13e), indicating that $\mathrm{Co}$ and $\mathrm{Ni}$ can replace Fe by direct-ion exchange [52]. PyIII is characterized by higher $\mathrm{Co}$ and Ni contents than PyII (Figure 13d). Element mapping by electron microprobe also indicates that $\mathrm{Co}$ and $\mathrm{Ni}$ are incorporated in the pyrite crystal lattice and exhibit compositional zoning in pyrite grains (Figures 8-10).

A positive correlation was observed between Se and Te on the Se-Te diagram, which can be divided into two distinct sub-areas (Figure 13g): Se-poor and Te-poor PyI and PyII and Se-rich and Te-rich PyIII. An obvious negative correlation exists between Te and S (Figure 13h), indicating that Te and Se distort the $S$ site in a similar way as the AsS dianion [53] and that more $S$ was replaced by Se and Te in PyIII. Au and Te show no correlation (Figure 13i).

Note the negative correlations between $\mathrm{Cu}$ and $\mathrm{Fe}$ in pyrite (Figure 13j), the positive correlations between $\mathrm{Au}$ and $\mathrm{Cu}$ (Figure 13k), and the fact that the concentration of $\mathrm{Cu}$ is approximately the same as that of $\mathrm{Au}$ (Figure 11).

\subsection{Gold in Pyrite}

The Au-As diagram (Figure 14a) shows that PyI (lower As) and PyII-2 (higher As) plot below the line of gold saturation, which reflects the incorporation of Au into pyrite in a metastable solid solution [50,54]; PyII-1, PyII-3, and PyIII plot near or above the line of gold saturation, which reflects the formation of Au nanoparticles by the cooling of hydrothermal fluid and/or supersaturation with respect to native $\mathrm{Au}$ (Figure 14a) [50,54]. EPMA X-ray elemental maps also show that $\mathrm{Au}$ is distributed as invisible gold within the arsenian pyrite; additionally, visible gold fills microfractures in PyII or occurs as inclusions in PyIII (Figures 6, 9 and 10). Previous studies have established that invisible gold is most likely incorporated into metastable solid solution, which is controlled by chemisorption at As-rich, Fe-deficient surface sites, temperature, or the amounts of other trace elements $[8,10,49,52,54]$. It is interesting that Au does not display the strong sectoral preference noted for As in arsenian pyrite. Furthermore, there is a clear negative correlation between $\mathrm{Au}$ and Fe concentrations (Figure 14b); Fe vacancies may be a major cause of the invisible Au precipitation in PyII and PyIII, thus indicating the substitution mechanism of $\mathrm{Au}=\mathrm{Fe}$ [54]. However, the chemical state of invisible gold in pyrite remains controversial [49]. The fact that $\mathrm{Co}, \mathrm{Ni}$, and $\mathrm{Cu}$ exhibit positive correlations with $\mathrm{Au}$ (Figure 13f,k) and that there is a negative correlation between $\mathrm{Au}+\mathrm{Cu}+\mathrm{Co}+\mathrm{Ni}$ and Fe reflect the coupled reaction of $\mathrm{Au}^{+}+\mathrm{Cu}^{+}+\mathrm{Co}^{2+}+\mathrm{Ni}^{2+} \leftrightarrow 3 \mathrm{Fe}^{2+}$ (Figure 14c) [52].

There are two alternative mechanisms of gold release: (1) gold is remobilized from the sulfide lattice by a solid-state process or a coupled dissolution-reprecipitation reaction (CDRR) [3,55-59]; or (2) it is introduced during the overprinting caused by hydrothermal fluids [3,57]. EPMA X-ray elemental maps also show that invisible gold is uniformly distributed within arsenian pyrite, whereas visible gold fills microfractures in PyII or occurs as inclusions in PyIII (Figures 6, 7f, 8f, 9e and 10e). Co, $\mathrm{Ni}$, and As preserve initial oscillatory zonation patterns in PyII, but they are uniformly distributed in PyIII (Figure 9). A fluid-assisted method of remobilization would explain why some elements are remobilized but others ( $\mathrm{Te}, \mathrm{Se}, \mathrm{Co}$, and $\mathrm{Ni}$ ) are clearly not, in addition to supporting the observation of micropores tied to the observed nanoscale and fine particles [59]. The concentrations of $\mathrm{Co}, \mathrm{Ni}$, Se and Te are higher in PyIII than in PyII (Figure 11). Therefore, we conclude that the possible upgrading of Au may have occurred if either the fluid became supersaturated and precipitated the majority of gold at end of the mineralization or if it underwent remobilization by CDRR (e.g., Figure 6e,i) [60]. 

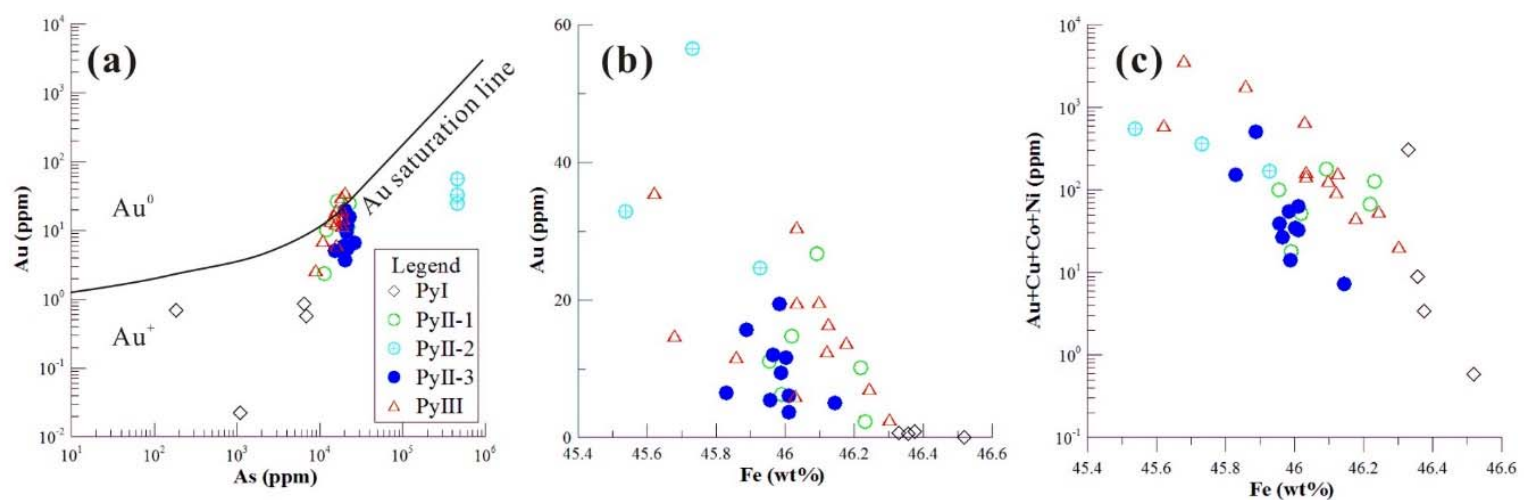

Figure 14. Plots of pyrite compositions (LA-ICP-MS data). (a) Au-As plot of pyrite is modified from Ref. [50,61]. (b) plot of Fe vs. Au; (c) plot of Fe vs. $\mathrm{Au}+\mathrm{Cu}+\mathrm{Co}+\mathrm{Ni}$.

\subsection{Implications for Fluid Evolution}

The textures and trace element compositions of pyrite can potentially be used as robust indicators of fluid composition $[15,43,53,61,62]$.

More reducing conditions occurred in stage III, as demonstrated by the minor redissolution of pyrite and arsenopyrite (Figure $6 \mathrm{~d}, \mathrm{~g}$ ) $[63,64]$ and the change from a pyrite-arsenopyrite assemblage to a pyrite-pyrrhotite assemblage [65-67]; this would have promoted the deposition of gold and especially caused the conversion of pyrite (high sulfur content) to pyrrhotite (low sulfur content) in stage III, which is associated with native gold (Figure 6i) [65-69].

The $\mathrm{Co} / \mathrm{Ni}$ ratio in pyrite has been used by many authors as an empirical indicator of the depositional environment [15,70-72]. The presence of chemical zoning in the pyrite of the Zhengchong gold deposit may reflect fluctuations in temperature and $\mathrm{pH}[15,72]$. Co/Ni ratios $(<1)$ with low standard deviations are generally accepted to represent pyrite of sedimentary origin $[18,46,47,71]$. The $\mathrm{Co} / \mathrm{Ni}$ ratios of the arsenian pyrite in the Zhengchong gold deposit vary; in general, the average $\mathrm{Co} / \mathrm{Ni}$ values are 0.15 in PyI, 0.16 in PyII, and 0.38 in PyIII (Figure 15a), thus apparently indicating that the mineralization may have been caused by metamorphic hydrothermal fluids [69]. The higher $\mathrm{Co}$ and Ni concentrations (Figure 13d) and higher Co/Ni ratios (Figure 15a) observed from PyII to PyIII may result from a decrease in temperature [15,72].

Variations in Se and Te have commonly been attributed to changes in fluid temperature and redox conditions [53,73-77]. Slightly neutral, mildly reduced fluids can efficiently transport $\mathrm{Au}, \mathrm{a} \mathrm{Au}(\mathrm{HS})_{2}{ }^{-}$ can also carry $\sim 100 \mathrm{ppb}$ Te at $300{ }^{\circ} \mathrm{C}[77,78]$. Te-rich pyrite precipitates from reduced fluids due to fluid boiling and fluid-rock interactions $[53,79]$. In contrast, Se-rich pyrite usually forms from low-temperature fluids, regardless of the $f \mathrm{O}_{2}$ and $\mathrm{pH}$ values of the fluids [53,79]. The concentrations of Se and Te are higher in PyIII than they are in PyII (Figure 11). The average Se/Te values are 87.19 in PyI, 72.48 in PyII, and 5.36 in PyIII (Table 3). The Se/Te ratios decrease from PyI to PyIII (Figure 15b,c). The clear differences in the Se and Te concentrations and Se/Te ratios between PyII and PyIII represent two different conditions. These data reveal that temperature is the key factor in this change and that the temperature was lower during stage III [5,79].

Field and petrographic observations of most gold deposit in NEHP generally reveal four-stage mineral paragenesis, especially the quartz-pyrite-arsenopyrite and quartz-polysulfide stages, like the Zhengchong gold deposits (e.g., Wangu, Huangjindong) [24], which also consistent with worldwide orogenic gold deposit belts (e.g., the Yilgarn Craton) [80,81]. Belousov et al. (2016) subdivide orogenic gold deposit in the Yilgarn Craton into $\mathrm{Au}-\mathrm{As}$ and $\mathrm{Au}$-Te groups based upon pyrite geochemistry, which may correspond to the PyII and PyIII (Figures 11 and 13a) [81]. For example, in the Yilgarn Craton, $65 \%$ of orogenic gold deposit pyrites have $\mathrm{Co} / \mathrm{Ni}<1$, Au-As association orogenic gold deposits show $\mathrm{Se} / \mathrm{Te}>5$, in contrast of Au-Te ores [81]. These characteristics fit the Zhengchong gold deposit (Figure 15). 

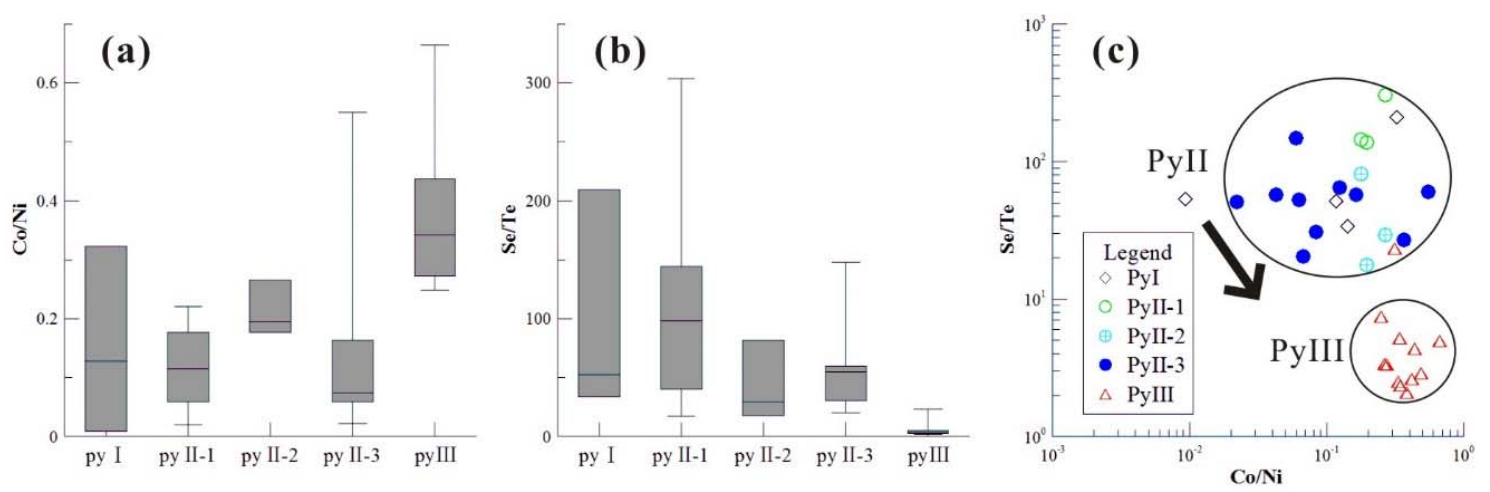

Figure 15. (a,b) Comparative box plot of the geochemistry of all generations of pyrite (LA-ICP-MS data), illustrating the range of ratios of $\mathrm{Co}-\mathrm{Ni}$ and Se-Te. (c) Scatter plot of Se/Te and Co/Ni ratios, illustrating the distinct differences between PyII and PyIII (LA-ICP-MS data).

\section{Conclusions}

Our textural observations, pyrite generations, EPMA data, LA-ICP-MS data and elemental maps demonstrate the complexities of the pyrites at Zhengchong, which reflect the evolution of hydrothermal events. The results can be used to pinpoint the evolution of fluid during the genesis of the Zhengchong orogenic gold deposit.

(1) Four stages and three generations of pyrite can be distinguished at Zhengchong. The earliest sulfide mineralization produced unzoned, trace element-poor pyrite (PyI). Significant amounts of oscillatory zoned and As-, Co-, and Ni-rich pyrite (PyII) formed coevally with arsenopyrite and tetrahedrite mineralization. PyII is overprinted by later hydrothermal fluids. Then, inclusion-rich PyIII precipitated in massive sulfide veins or veinlets. PyII and PyIII are arsenian pyrite and represent the main Au-bearing minerals.

(2) PyI records the lowest concentrations of $\mathrm{Au}$. PyII and PyIII have similar amounts of $\mathrm{Au}, \mathrm{Cu}, \mathrm{Pb}$, $\mathrm{Zn}$, and $\mathrm{Bi}$, but PyIII is more enriched in $\mathrm{Co}, \mathrm{Ni}, \mathrm{Te}$, and Se. The substitution of $\mathrm{As}$, Se and Te for $\mathrm{S}$ and that of $\mathrm{Co}$ and $\mathrm{Ni}$ for Fe occurred by direct-ion exchange.

(3) The EPMA X-ray elemental maps and LA-ICP-MS point analyses show that invisible gold is uniformly distributed within the arsenian pyrite and that visible gold fills microfractures in PyII or occurs as inclusions in PyIII. $\mathrm{Co}, \mathrm{Ni}, \mathrm{Cu}$ exhibit positive correlations with $\mathrm{Au}$ and a negative correlation between $\mathrm{Au}+\mathrm{Cu}+\mathrm{Co}+\mathrm{Ni}$ and Fe reflect that Fe vacancies may have been a major cause of the precipitation of invisible $\mathrm{Au}$ and other metal elements in pyrite structure.

(4) There are systematic trace element differences between the three generations of pyrite (PyI, PyII, PyIII). The more Co, Ni and Se, Te substitutions that occurred for Fe and S, respectively, the greater the increase in the $\mathrm{Co} / \mathrm{Ni}$ ratio $(<1)$ and decrease in the Se/Te ratio $(<10)$ in stage III, respectively, indicating that more reduced, lower-temperature metamorphic hydrothermal fluid was present in stage III.

Author Contributions: Y.-J.S. and W.-S.W. conceived and designed the experiments; Y.Z. performed the experiments; W.-S.W. and Q.-Q.L. analyzed the data; W.-S.W., Q.-Q.L. and Y.-J.S. wrote the paper.

Funding: This research was jointly funded by General Financial Grant from the China Postdoctoral Science Foundation (2017M622596) and Hunan Province Geological Scientific Research project of Land and Resources of Hunan Province (2016-04).

Acknowledgments: We sincerely appreciate the detailed and constructive reviews and suggestions from two anonymous reviewers, which greatly improved this paper. We especially thank Yu Zhang for helping with the LA-ICP-MS trace element analyses.

Conflicts of Interest: The authors declare no conflict of interest. 


\section{References}

1. Groves, D.I.; Goldfarb, R.J.; Gebre-Mariam, M.; Hagemann, S.G.; Robert, F. Orogenic gold deposits: A proposed classification in the context of their crustal distribution and relationship to other gold deposit types. Ore Geol. Rev. 1998, 13, 7-27. [CrossRef]

2. Lang, J.R.; Baker, T. Intrusion-related gold systems: The present level of understanding. Miner. Depos. 2001, 36, 477-489. [CrossRef]

3. Groves, D.I.; Goldfarb, R.J.; Robert, F.; Hart, C.J.R. Gold Deposits in Metamorphic Belts: Overview of Current Understanding, Outstanding problems, future research, and exploration signifcance. Econ. Geol. 2003, 98, 1-29.

4. Groves, D.I.; Vielreicher, R.M.; Goldfarb, R.J.; Condie, K.C. Controls on the heterogeneous distribution of mineral deposits through time. Geol. Soc. Lond. Spec. Publ. 2005, 248, 11-14. [CrossRef]

5. Goldfarb, R.J.; Groves, D.I.; Gardoll, S. Orogenic gold and geologic time: A global synthesis. Ore Geol. Rev. 2001, 18, 1-75. [CrossRef]

6. Hart, C.J. Reduced Intrusion-related Gold Systems. In Mineral Deposits of Canada: A Synthesis of Major Deposit-Types, District Metallogeny, the Evolution of Geological Provinces, and Exploration Methods; Goodfellow, W.D., Ed.; Geological Association of Canada, Mineral Deposits Division: St. John's, NL, Canada, 2007; pp. 95-112.

7. Phillips, G.N.; Powell, R. Formation of gold deposits: Review and evaluation of the continuum model. Earth-Sci. Rev. 2009, 94, 1-21. [CrossRef]

8. Tomkins, A.G. On the source of orogenic gold. Geology 2013, 41, 1255-1256. [CrossRef]

9. Micklethwaite, S.; Cox, S.F. Progressive fault triggering and fluid flow in aftershock domains: Examples from mineralized Archaean fault systems. Earth Planet. Sci. Lett. 2006, 250, 318-330. [CrossRef]

10. Weatherley, D.K.; Henley, R.W. Flash vaporization during earthquakes evidenced by gold deposits. Nat. Geosci. 2013, 6, 294-298. [CrossRef]

11. Stefánsson, A.; Seward, T.M. Gold(I) complexing in aqueous sulphide solutions to $500{ }^{\circ} \mathrm{C}$ at 500 bar. Geochim. Cosmochim. Acta 2004, 68, 4121-4143. [CrossRef]

12. Goryachev, N.A.; Pirajno, F. Gold deposits and gold metallogeny of Far East Russia. Ore Geol. Rev. 2014, 59, 123-151. [CrossRef]

13. Molnár, F.; Mänttäri, I.; O’Brien, H.; Lahaye, Y.; Pakkanen, L.; Bo, J.; Käpyaho, A.; Sorjonen-Ward, P.; Whitehouse, M.; Sakellaris, G. Boron, sulphur and copper isotope systematics in the orogenic gold deposits of the Archaean Hattu schist belt, eastern Finland. Ore Geol. Rev. 2016, 77, 133-162. [CrossRef]

14. Harlan, S.S.; Vielreicher, R.M.; Mortensen, J.M.; Bradley, D.C.; Goldfarb, R.J.; Snee, L.W.; Till, A.B. Geology and timing of ore formation in the willow creek gold district, Talkeetna mountains, Southern Alaska. Econ. Geol. 2017, 112, 1177-1204. [CrossRef]

15. Craig, J.R.; Vokes, F.M.; Solberg, T.N. Pyrite: Physical and chemical textures. Miner. Depos. 1998, 34, 82-101. [CrossRef]

16. Cook, N.J.; Ciobanu, C.L.; Spry, P.G.; Voudouris, P.; Ofigcp, T.P. Understanding gold-(silver)-telluride(selenide) mineral deposits. Episodes 2009, 32, 249-263.

17. Zhao, H.X.; Frimmel, H.E.; Jiang, S.Y.; Dai, B.Z. LA-ICP-MS trace element analysis of pyrite from the Xiaoqinling gold district, China: Implications for ore genesis. Ore Geol. Rev. 2011, 43, 142-153. [CrossRef]

18. Zhang, J.; Deng, J.; Chen, H.Y.; Yang, L.Q.; Cooke, D.; Danyushevsky, L.; Gong, Q.J. LA-ICP-MS trace element analysis of pyrite from the Chang'an gold deposit, Sanjiang region, China: Implication for ore-forming process. Gondwana Res. 2014, 26, 557-575. [CrossRef]

19. Fleet, M.E.; Chryssoulis, S.L.; Davidson, R.; Weisener, C.G.; Maclean, P.J. Arsenian pyrite from gold deposits: $\mathrm{Au}$ and as distribution investigated by SIMS and EPM, and color staining and surface oxidation by XPS and LIMS. Can. Mineral. 1993, 31, 1-17.

20. Agangi, A.; Axel, H.; Sser, W.U. Pyrite Zoning as a Record of Mineralization in the Ventersdorp Contact Reef, Witwatersrand Basin, South Africa. Econ. Geol. 2013, 108, 1243-1273. [CrossRef]

21. Mumin, A.H.; Fleet, M.E.; Chryssoulis, S.L. Gold mineralization in As-rich mesothermal gold ores of the Bogosu-Prestea mining district of the Ashanti Gold Belt, Ghana: Remobilization of "invisible" gold. Miner. Depos. 1994, 29, 445-460. [CrossRef] 
22. Zhu, Y.F.; Fang, A.; Tan, J.J. Geochemistry of hydrothermal gold deposits: A review. Geosci. Front. 2011, 02, 367-374. [CrossRef]

23. Deng, T.; Xu, D.R.; Chi, G.X.; Wang, Z.L.; Jiao, Q.Q.; Ning, J.T.; Dong, G.J.; Zou, F.H. Geology, geochronology, geochemistry and ore genesis of the Wangu gold deposit in northeastern Hunan province, Jiangnan Orogen, South China. Ore Geol. Rev. 2017, 88, 619-637. [CrossRef]

24. Xu, D.R.; Deng, T.; Chi, G.X.; Wang, Z.L.; Zou, F.H.; Zhang, J.L.; Zou, S.H. Gold mineralization in the Jiangnan orogenic belt of south china: Geological, geochemical and geochronological characteristics, ore deposit-type and geodynamic setting. Ore Geol. Rev. 2017, 88, 565-618. [CrossRef]

25. Mao, J.; Li, H. Research on genesis of the gold deposits in the Jiangnan terrain. Geochimica 1997, $26,71-81$. (In Chinese with English abstract)

26. Peng, B.; Frei, R. Nd-Sr-Pb isotopic constraints on metal and fluid sources in $\mathrm{W}-\mathrm{Sb}-\mathrm{Au}$ mineralization at Woxi and Liaojiaping (Western Hunan, China). Miner. Depos. 2004, 39, 313-327. [CrossRef]

27. Gu, X.; Schulz, O.; Vavtar, F.; Liu, J.; Zheng, M.; Fu, S. Rare earth element geochemistry of the Woxi W-Sb-Au deposit, Hunan province, South China. Ore Geol. Rev. 2007, 31, 319-336. [CrossRef]

28. Gu, X.; Zhang, Y.; Schulz, O.; Vavtar, F.; Liu, J.; Zheng, M.; Zheng, L. The Woxi W-Sb-Au deposit in Hunan, South China: An example of Late Proterozoic sedimentary exhalative (SEDEX) mineralization. J. Asian Earth Sci. 2012, 57, 54-75. [CrossRef]

29. Dong, G.J.; Xu, D.R.; Wang, L.; Chen, G.H.; He, Z.L.; Fu, G.G.; Wu, J.; Wang, Z.L. Determination of mineralizing age on gold ore deposits in the eastern Hunan province, south China and isotopic tracking on ore-forming fluids-re-discussion gold ore deposit type. Geotecton. Metallog. 2008, 32, 482-491. (In Chinese with English abstract)

30. Zhao, C.; Ni, P.; Wang, G.G.; Ding, J.Y.; Chen, H.; Zhao, K.D.; Cai, Y.T.; Xu, Y.F. Geology, fluid inclusion, and isotope constraints on ore genesis of the Neoproterozoic Jinshan orogenic gold deposit, South China. Geofluids 2013, 13, 506-527. [CrossRef]

31. Goldfarb, R.J.; Taylor, R.D.; Collins, G.S.; Goryachev, N.A.; Orlandini, O.F. Phanerozoic continental growth and gold metallogeny of Asia. Gondwana Res. 2014, 25, 48-102. [CrossRef]

32. Deng, J.; Wang, Q. Gold mineralization in China: Metallogenic provinces, deposit types and tectonic framework. Gondwana Res. 2015, 36, 219-274. [CrossRef]

33. Zhu, Y.; Peng, J. Infrared microthermometric and noble gas isotope study of fluid inclusions in ore minerals at the Woxi orogenic Au-Sb-W deposit, western Hunan, South China. Ore Geol. Rev. 2015, 65, 55-69. [CrossRef]

34. $\mathrm{Li}, \mathrm{X} . \mathrm{H}$. U-Pb zircon ages of granites from the southern margin of the Yangtze Block: Timing of Neoproterozoic Jinning Orogeny in SE China and implications for Rodinia assembly. Precambr. Res. 1999, 97, 43-57. [CrossRef]

35. Zhou, M.F.; Yan, D.P.; Kennedy, A.K.; Li, Y.; Ding, J. SHRIMP U-Pb zircon geochronological and geochemical evidence for Neoproterozoic arc-magmatism along the western margin of the Yangtze Block, South China. Earth Planet. Sci. Lett. 2002, 196, 51-67. [CrossRef]

36. Zhou, M.F.; Kennedy, A.K.; Sun, M.; Malpas, J.; Lesher, C.M. Neoproterozoic arcrelated mafic intrusions along the northern margin of South China: Implications for the accretion of Rodinia. J. Geol. 2002, 110, 611-618. [CrossRef]

37. Yao, J.L.; Shu, L.S.; Santosh, M.; Zhao, G.C. Neoproterozoic arc-related mafic-ultramafic rocks and syn-collision granite from the western segment of the Jiangnan Orogen, South China: Constraints on the Neoproterozoic assembly of the Yangtze and Cathaysia Blocks. Precambr. Res. 2014, 243, 39-62. [CrossRef]

38. Zhao, G.C. Jiangnan Orogen in South China: Developing from divergent double subduction. Gondwana Res. 2015, 27, 1173-1180. [CrossRef]

39. Zhou, X.M.; Sun, T.; Shen, W.Z.; Shu, L.S.; Niu, Y.L. Petrogenesis of Mesozoic granitoids and volcanic rocks in South China: A response to tectonic evolution. Episodes 2006, 29, 26-33.

40. Li, Z.X.; Li, X.H. Formation of the $1300-\mathrm{km}$-wide intracontinental orogen and postorogenic magmatic province in Mesozoic South China: A flat-slab subduction model. Geology 2007, 35, 179-182. [CrossRef]

41. Zhu, K.Y.; Li, Z.X.; Xu, X.S.; Wilde, S.A. A Mesozoic Andean-type orogenic cycle in southeastern China as recorded by granitoid evolution. Am. J. Sci. 2014, 314, 187-234. [CrossRef]

42. Wang, Z.L.; Xu, D.R.; Chi, G.X.; Shao, Y.J.; Lai, J.Q.; Deng, T.; Guo, F.; Wang, Z.; Dong, G.J.; Ning, J.T.; et al. Mineralogical and isotopic constraints on the genesis of the Jingchong $\mathrm{Co}-\mathrm{Cu}$ polymetallic ore deposit in northeastern Hunan Province, South China. Ore Geol. Rev. 2017, 88, 638-654. [CrossRef] 
43. Large, R.R.; Danyushevsky, L.; Hollit, C.; Maslennikov, V.; Meefre, S.; Gilbert, S.; Bull, S.; Scott, R.; Emsbo, P.; Thomas, H.; et al. Gold and trace element zonation in pyrite using a laser imaging technique: Implications for the timing of gold in orogenic and Carlin-style sediment-hosted deposits. Econ. Geol. 2009, 104, 635-668. [CrossRef]

44. Longerich, H.P.; Jackson, S.E.; Gunther, D. Laser ablation inductively coupled plasma mass spectrometric transient signal data acquisition and analyte concentration calculation. J. Anal. At. Spectrom. 1996, 11, 899-904. [CrossRef]

45. Danyushevsky, L.V.; Robinson, P.; Gilbert, S.; Norman, M.; Large, R.; McGoldrick, P.; Shelly, J.M.G. Routine quantitative multi-element analysis of sulphide minerals by laser ablation ICPMS: Standard development and consideration of matrix effects. Geochem. Explor. Environ. Anal. 2011, 11, 51-60. [CrossRef]

46. Thomas, H.V.; Large, R.R.; Bull, S.W.; Maslennikov, V.; Berry, R.F.; Fraser, R.F.; Froud, S.; Moye, R. Pyrite and pyrrhotite textures and composition in sediments, laminated quartz veins, and reefs at Bendigo gold mine, Australia: Insights for ore genesis. Econ. Geol. 2011, 106, 1-31. [CrossRef]

47. Deol, S.S.; Deb, M.M.; Large, R.R.; Gilbert, S. LA-ICPMS and EPMA studies of pyrite, arsenopyrite and loellingite from the Bhukia-Jagpura gold prospect, southern Rajasthan, India: Implications for ore genesis and gold remobilization. Chem. Geol. 2012, 326-327, 72-87. [CrossRef]

48. Li, N.; Deng, J.; Yang, L.Q.; Goldfarb, R.J.; Zhang, C.; Marsh, E.; Lei, S.B.; Koenig, A.; Lowers, H. Paragenesis and geochemistry of ore minerals in the epizonal gold deposits of the Yangshan gold belt, West Qinling, China. Miner. Depos. 2014, 49, 427-449. [CrossRef]

49. Fleet, M.E.; Mumin, A.H. Gold-bearing arsenian pyrite and marcasite and arsenopyrite from Carlin Trend gold deposits and laboratory synthesis. Am. Mineral. 1997, 82, 182-193. [CrossRef]

50. Reich, M.; Kesler, S.E.; Utsunomiya, S.; Palenik, C.S.; Chryssoulis, S.L.; Ewing, R.C. Solubility of gold in arsenian pyrite. Geochim. Cosmochim. Acta 2005, 69, 2781-2796. [CrossRef]

51. Cook, N.J.; Spry, P.G.; Vokes, F.M. Mineralogy and textural relationships among sulphosalts and related minerals in the Bleikvassli $\mathrm{Zn}-\mathrm{Pb}-(\mathrm{Cu})$ deposit, Nordland, Norway. Miner. Depos. 1998, 34, 35-56. [CrossRef]

52. Chouinard, A.; Paquette, J.; Williams-Jones, A.E. Crystallographic controls on trace-element incorporation in auriferous pyrite from the Pascua epithermal high-sulfidation deposit, Chile-Argentina. Can. Mineral. 2005, 43, 951-963. [CrossRef]

53. Keith, M.; Smith, D.J.; Jenkin, G.R.T.; Holwell, D.A.; Dye, M.D. A review of Te and Se systematics in hydrothermal pyrite from precious metal deposits: Insights into ore-forming processes. Ore Geol. Rev. 2017, 96, 269-282. [CrossRef]

54. Deditius, A.P.; Reich, M.; Kesler, S.E.; Utsunomiya, S.; Chryssoulis, S.L.; Walshe, J.; Ewing, R.C. The coupled geochemistry of Au and As in pyrite from hydrothermal ore deposits. Geochim. Cosmochim. Acta 2014, 140, 644-670. [CrossRef]

55. Tomkins, A.G. Mobilization of Gold as a Polymetallic Melt during Pelite Anatexis at the Challenger Deposit, South Australia: A Metamorphosed Archean Gold Deposit. Econ. Geol. 2002, 97, 1249-1271. [CrossRef]

56. Wagner, T.; Klemd, R.; Wenzel, T.; Mattsson, B. Gold upgrading in metamorphosed massive sulfide ore deposits: Direct evidence from laser-ablation-inductively coupled plasma-mass spectrometry analysis of invisible gold. Geology 2007, 35, 775-778. [CrossRef]

57. Morey, A.A.; Tomkins, A.G.; Bierlein, F.P.; Weinberg, R.F.; Davidson, G.J. Bimodal distribution of gold in pyrite and arsenopyrite: Examples from the Archean Boorara and Bardoc shear systems, Yilgarn craton, Western Australia. Econ. Geol. 2008, 10, 599-614. [CrossRef]

58. Putnis, A. Mineral replacement reactions: From macroscopic observations to microscopic mechanisms. Mineral. Mag. 2002, 66, 689-708. [CrossRef]

59. Xia, F.; Brugger, J.; Chen, G.; Ngothai, Y.; O'Neill, B.; Putnis, A.; Ping, A. Mechanism and kinetics of pseudomorphic mineral replacement reactions: A case study of the replacement of pentlandite by violarite. Geochim. Cosmochim. Acta 2009, 73, 1945-1969. [CrossRef]

60. Sung, Y.H.; Brugger, J.; Ciobanu, C.L.; Pring, A.; Skinner, W.; Nugus, M. Invisible gold in arsenian pyrite and arsenopyrite from a multistage archaean gold deposit: Sunrise Dam, eastern goldfields province, western Australia. Miner. Depos. 2009, 44, 765. [CrossRef]

61. Reich, M.; Deditius, A.; Chryssoulis, S.; Li, J.W.; Ma, C.Q.; Parada, M.A.; Barra, F.; Mittermayr, F. Pyrite as a record of hydrothermal fluid evolution in a porphyry copper system: A sims/empa trace element study. Geochim. Cosmochim. Acta 2013, 104, 42-62. [CrossRef] 
62. Wohlgemuth-Ueberwasser, C.C.; Viljoen, F.; Petersen, S.; Vorster, C. Distribution and solubility limits of trace elements in hydrothermal black smoker sulfides: An in-situ LA-ICP-MS study. Geochim. Cosmochim. Acta 2015, 159, 16-41. [CrossRef]

63. Heinrich, C.A.; Eadington, P.J. Thermodynamic predictions of hydrothermal chemistry of arsenic and their significance for the paragenic sequence of some cassiterite-arsenopyrite-base metal sulfide deposits. Econ. Geol. 1986, 81, 511-529. [CrossRef]

64. Pokrovski, G.S.; Kara, S.; Roux, J. Stability and solubility of arsenopyrite, FeAsS, in crustal fluids. Geochim. Cosmochim. Acta 2002, 66, 2361-2378. [CrossRef]

65. Ferry, J.M. Petrology of graphitic sulfide-rich schists from South- Central Maine- an example of desulfidation during prograde regional metamorphism. Am. Mineral. 1981, 66, 908-931.

66. Hoschek, G. Alpine metamorphism of calcareous metasediments in the Western Hohe Tauern, tyrol: Mineral equilibria in COHS fluids. Contrib. Mineral. Petrol. 1984, 87, 129-137. [CrossRef]

67. Hall, A.J. Pyrite-Pyrrhotine Redox Reactions in Nature. Mineral. Mag. 1986, 50, 223-229. [CrossRef]

68. Phillips, G.N.; Powell, R. Formation of gold deposits: A metamorphic devolatilization model. J. Metamorph. Geol. 2010, 28, 689-718. [CrossRef]

69. Finch, E.G.; Tomkins, A.G. Pyrite-pyrrhotite stability in a metamorphic aureole: Implications for orogenic gold genesis. Econ. Geol. 2017, 112, 661-674. [CrossRef]

70. Bralia, A.; Sabatini, G.; Troja, F. A revaluation of the Co/Ni ratio in pyrite as geochemical tool in ore genesis problems. Miner. Depos. 1979, 14, 353-374. [CrossRef]

71. Raymond, O.L. Pyrite composition and ore genesis in the Prince Lyell copper deposit, Mt Lyell mineral field, western Tasmania, Australia. Ore Geol. Rev. 1996, 10, 231-250. [CrossRef]

72. Clark, C.; Grguric, B.; Mumm, A.S. Genetic implications of pyrite chemistry from the Palaeoproterozoic Olary Domain and overlying Neoproterozoic Adelaidean sequences, northeastern South Australia. Ore Geol. Rev. 2004, 25, 237-257. [CrossRef]

73. Cook, N.J.; Ciobanu, C.L.; Mao, J. Textural control on gold distribution in As-free pyrite from the Dongping, Huangtuliang and Hougou gold deposits, North China Craton (Hebei Province, China). Chem. Geol. 2009, 264, 101-121. [CrossRef]

74. Keith, M.; Häckel, F.; Haase, K.M.; Schwarz-Schampera, U.; Klemd, R. Trace element systematics of pyrite from submarine hydrothermal vents. Ore Geol. Rev. 2016, 72, 728-745. [CrossRef]

75. Keith, M.; Haase, K.M.; Klemd, R.; Krumm, S.; Strauss, H. Systematic variations in the trace element and sulphur isotope composition of pyrite with stratigraphic depth in the Skouriotissa volcanic-hosted massive sulphide deposit, Troodos ophiolite, Cyprus. Chem. Geol. 2016, 423, 7-18. [CrossRef]

76. Gao, S.; Xu, H.; Li, S.G.; Santosh, M.; Zhang, D.S.; Yang, L.J.; Quan, A.L. Hydrothermal alteration and ore-forming fluids associated with gold-tellurium mineralization in the Dongping gold deposit, China. Ore Geol. Rev. 2017, 80, 166-184. [CrossRef]

77. Grundler, P.V.; Brugger, J.; Etschmann, B.E.; Helm, L.; Liu, W.; Spry, P.G.; Tian, Y.; Testemale, D.; Pring, A. Speciation of aqueous tellurium(IV) in hydrothermal solutions and vapors, and the role of oxidized tellurium species in Te transport and gold deposition. Geochim. Cosmochim. Acta 2013, 120, 298-325. [CrossRef]

78. Liu, W.; Etschmann, B.; Testemale, D.; Hazemann, J.L.; Rempel, K.; Müller, H.; Brugger, J. Gold transport in hydrothermal fluids: Competition among the $\mathrm{Cl}^{-}, \mathrm{Br}^{-}, \mathrm{HS}^{-}$, and $\mathrm{NH}_{3}$ (aq), ligands. Chem. Geol. 2014, 376, 11-19. [CrossRef]

79. Huston, D.L.; Sie, S.H.; Suter, G.F.; Cooke, D.R.; Both, R.A. Trace elements in sulfide minerals from eastern australian volcanic-hosted massive sulfide deposits; part I, proton microprobe analyses of pyrite, chalcopyrite, and sphalerite, and part II, selenium levels in pyrite; comparison with $\delta^{34} \mathrm{~S}$ values and implic. Econ. Geol. 1995, 90, 1167-1196. [CrossRef] 
80. Goldfarb, R.J.; Baker, T.; Dubé, B.; Groves, D.I.; Hart, C.J.R.; Gosselin, P. Distribution, character, and genesis of gold deposits in metamorphic terranes. In Economic Geology 100th Anniversary Volume; Society of Economic Geologists: Littleton, CO, USA, 2005; pp. 407-450.

81. Belousov, I.; Large, R.R.; Meffre, S.; Danyushevsky, L.V.; Steadman, J.; Beardsmore, T. Pyrite compositions from VHMS and orogenic Au deposits in the Yilgarn Craton, Western Australia: Implications for gold and copper exploration. Ore Geol. Rev. 2016, 79, 474-499. [CrossRef]

(C) 2018 by the authors. Licensee MDPI, Basel, Switzerland. This article is an open access article distributed under the terms and conditions of the Creative Commons Attribution (CC BY) license (http:/ / creativecommons.org/licenses/by/4.0/). 